IZA DP No. 6127

Job Preferences as Revealed by Employee Initiated Job Changes

Christian Grund

November 2011 


\title{
Job Preferences as Revealed by Employee Initiated Job Changes
}

\author{
Christian Grund \\ University of Duisburg-Essen \\ and IZA
}

\section{Discussion Paper No. 6127 \\ November 2011}

\author{
IZA \\ P.O. Box 7240 \\ 53072 Bonn \\ Germany \\ Phone: +49-228-3894-0 \\ Fax: +49-228-3894-180 \\ E-mail: iza@iza.org
}

\begin{abstract}
Any opinions expressed here are those of the author(s) and not those of IZA. Research published in this series may include views on policy, but the institute itself takes no institutional policy positions.

The Institute for the Study of Labor (IZA) in Bonn is a local and virtual international research center and a place of communication between science, politics and business. IZA is an independent nonprofit organization supported by Deutsche Post Foundation. The center is associated with the University of Bonn and offers a stimulating research environment through its international network, workshops and conferences, data service, project support, research visits and doctoral program. IZA engages in (i) original and internationally competitive research in all fields of labor economics, (ii) development of policy concepts, and (iii) dissemination of research results and concepts to the interested public.
\end{abstract}

IZA Discussion Papers often represent preliminary work and are circulated to encourage discussion. Citation of such a paper should account for its provisional character. A revised version may be available directly from the author. 
IZA Discussion Paper No. 6127

November 2011

\section{ABSTRACT}

\section{Job Preferences as Revealed by Employee Initiated Job Changes*}

Many previous studies try to discover job preferences by directly asking individuals. Since it is not sure, whether answers to these surveys are relevant for actual behaviour, this empirical examination offers a new approach based on representative German data. Employees who quit their job and find a new one, compare the two jobs with respect to eight job characteristics: type of work, pay, chances of promotion, work load, commuting time, work hour regulations, fringe benefits and security against loss of job. It is argued that the observation of many improvements (and few declines) for a certain attribute indicates a particular relevance and high preference for this attribute. It turns out that pay and type of work are most important for employees in this sense. Differences across subgroups of employees with respect to individual characteristics such as sex and age are explored. Those between East- and West-Germany diminish over time.

JEL Classification: M5, J28, J63

Keywords: $\quad$ job characteristics, job changes, job preferences, quits

Corresponding author:

Christian Grund

Universität Duisburg-Essen

Mercator School of Management

Lehrstuhl für Organisations- und Personalökonomie

Lotharstraße 65

47057 Duisburg

Germany

E-mail: christian.grund@uni-due.de

\footnotetext{
* Many thanks to Anja Göritz, Johannes Martin, Werner Nienhüser, Andreas Schmitt, Stefan Zimmermann and in particular to Ingo Weller for helpful comments.
} 


\section{Job Preferences as Revealed by Employee Initiated Job Changes}

\section{Introduction}

Individual preferences for jobs have already been considerably discussed in the social sciences during the last decades. Special aspects of single examinations include differences in preferences between men and women (Konrad et al. 2000 for an overview), changes in preferences over time (Jurgensen 1978), the relation between personality or ability and preferences (Bretz \& Judge 1994, Trank et al. 2002) and the effect of job attributes on organizational attractiveness (Powell 1984). From a firm's perspective it is important to generate knowledge about employees’ preferences for recruiting, retention and motivation reasons.

Most previous studies directly ask individuals about preferences. In these studies people have to rate or rank-order the relevance of certain job attributes. One possible problem of this approach is that socially desirable answers may occur so that true preferences are not revealed (Rynes 1991). In some other studies individuals are asked to choose among a variety of hypothetical jobs which differ in some controlled characteristics (Zedeck 1977, Rynes et al. 1983). Karren and Woodard Barringer (2002) discuss this policy-capturing approach.

Real world decisions of employees are not taken into account in the majority of previous studies. This contribution, therefore, offers an additional approach to explore job preferences of employees based on decisions on job change. I analyze employees who change their jobs and whose separations from their old jobs were initiated by themselves. Individuals who change jobs can evaluate, whether they actually face improvements or declines in important job characteristics. One can argue that a job attribute where the vast majority state improvements, seems to be an important one for employees. In contrast, an attribute for which many declines are observed, might not be such important for job choice. Therefore, I claim that the fraction of employees who state improvements and declines in job attributes are measures for revealed job preferences of employees.

The objective of this study is to suggest a new method to examine employees' job preferences and to apply this method to the hitherto hardly focused German case. Here, I both analyze the relative importance of certain job attributes and differences across subgroups of employees. 
I make use of a large representative sample of individuals living in Germany and identify about 5,000 cases of employee initiated job changes. Individuals compare their new job with the previous one according to eight job attributes: type of work, pay, chances of promotion, work load, commuting time, work hour regulations, fringe benefits and security against job loss. For each attribute individuals state whether they face an improvement, a decline or no change. Then it is, first of all, possible to examine differences between job attributes in general. Second, differences in job preferences across subgroups of individuals can be analyzed. The data used for this study include observations of over two decades from 1985 to 2006. Therefore, also changes over time can be considered, which includes the transformation process of the East German job market after re-unification in 1990.

This contribution will proceed as follows: First, I will give a brief overview of some decision theoretical approaches on job choice and previous empirical studies that aim to analyze job preferences. Afterwards, I will introduce the data and methodology of my own study followed by presenting the results. Finally, I discuss the results and conclude.

\section{Theoretical frameworks on decision making and job choice}

There is a variety of theoretical approaches concerning the question, how job choice or job change decisions are made or should be made. The approaches can be broadly divided to compensatory and non-compensatory decision strategies:

Compensatory decision making in job choice means that an individual evaluates some kind of weighted sum of several job attributes. An often cited example in the job preference literature is expectancy theory (Vroom 1996) which states that individual (job) choice decisions depend on "subjectively determined importance weight by the subjectively assessed degree to which the job offers that particular attribute” (Slaughter et al. 2006, 287). In consequence, there is no major difference to expected utility theory (Von Neumann \& Morgenstern 1953), which is still dominating in economics. Usually a certain utility - often represented by the wage - is linked to a job in main economic approaches. For instance, it is argued in search theory (Stigler 1961, 1962, Mortensen 1970) that job searching individuals will balance marginal costs of job search (mainly opportunity costs of time) against marginal benefits (wage increases). The multiattributive characteristic of a job is taken into account within the theory of compensating (wage) differentials that at the margin unpleasant job characteristics have to be compensated by higher wages or other benefits so that job attributes are rather substitutes 
than complements for individual employees. The argument already dates back to the $18^{\text {th }}$ century to Adam Smith's Wealth of Nations (see Smith 1976). For instance, Biddle and Zarkin (1988) report evidence for a substitution between wages and job injuries. In contrast it is often argued from a more general perspective that there are arguments for segmentation and segregation which lead to cumulated (dis-)advantages for individuals (see the contributions in Grusky 1994). These considerations are relevant for the analysis of job changes since it is important to know whether improvements in one attribute have to be "paid" by declines in others.

Recently, some behavioural advancements of economic theory suggest that not only the individual outcome determines individual decisions but also social norms (Benabou \& Tirole 2006, Sliwka 2007), intentions (Falk et al. 2008) or the comparison to the past (Farber 2008) or others (Fehr \& Schmidt 1999, Bolton \& Ockenfels 2000). The comparison to the past or others has already been integral part of prospect theory (Kahneman \& Tversky 1979), where it is assumed that decisions are made with respect to a reference point and positive (negative) deviations from this point are perceived as gains (losses). It is then argued that imminent losses are more relevant for human behaviour than possible gains, which is labelled by the term loss aversion. It follows in the multiattributive version of prospect theory (Tversky \& Kahneman 1991) that losses in one (job) attribute are likely to outweigh gains in other attributes. In consequence some kind of endowment effect (Thaler 1980) occurs, which states that the amount people are willing to pay for a good is lower than the amount the same people are willing to sell the same good. In this sense, the valuation of a good is increased inherently by its ownership, which leads to the assumption that job changes are only observed if considerable gains are expected. There is some support of expectancy theory (Wanous et al. 1983) as well as of multiattributive prospect theory respectively endowment effects in job choice and other decision situations (Hardie et al. 1993, Grund 2003).

In contrast to compensatory approaches, noncompensatory models of job choice decisions argue that some kind of lexicographic procedure (Payne et al. 1993) or limitation-by-aspects strategy is likely used. Tversky (1972) suggests a heuristic that alternatives not facing some minimum standards in important attributes are eliminated until only one alternative survives. Rynes et al. (1983) as well as Osborn (1990) report support for the relevance of noncompensatory decision strategies in job choice. Slaughter et al. (2006) find evidence that it depends on the certain kind of empirical procedure to examine job preferences, which framework has the most explanatory power. 
This short summary of some decision approaches on job choice is mainly to give a theoretical foundation to the topic. I will not directly test a certain theory against another in my empirical study. ${ }^{1}$ However, it is important to note that an underlying assumption of this study is that job change decisions are rational choices. Individuals make expectations about job attributes of alternatives and change jobs if they expect to benefit from that. Ex post wrong decisions may occur because expectations do not hold. I assume that there are no severe upward or downward biases in expectations so that on average positive and negative deviations balance for all job attributes. Therefore, the importance of a certain job attribute is expressed by a high (low) fraction of improvements (declines) in this attribute at observed job changes.

In the following I will give a brief overview of previous empirical studies for two reasons. First, I will compare my own results with a selection of these studies in the discussion. Second, I want to show that there are main conceptual differences of (most of) these studies to the paper at hand.

\section{Previous Studies}

A seminal paper on job preferences is that of Jurgensen (1978). He asks over 50,000 job applicants of one large public utility over three decades from 1946 to 1975 for a ranking of the importance of 10 job attributes. Individuals are also asked for an additional ranking of these attributes what they think others prefer. Individuals rank type of work and job security highest for themselves, but ascribe pay as the most important attribute to others. Slaughter et al. (2006) suggest that the results may be driven by social desirability of answers. Since Jurgensen's study and also many other examinations do not randomly draw subjects, possible selection effects have to be kept in mind. If low wages and a high degree of job security in a certain company are publicly known, for instance, individuals with corresponding preferences are likely to apply.

Turban, Eyring and Campion (1993) examine about 100 applicants of a large petrochemical company. Subjects are asked to rank the importance of eleven different job attributes. They rank "type of work" as the most important and working hours as the least important characteristic. After having accepted or rejected a job offer, subjects were also asked about ranks of attributes concerning the influence on their individual decision. Again the type of

\footnotetext{
${ }^{1}$ Explicit tests of decision theories are only possible with some kind of experimental approaches (e.g. Huber et al. 1971) and not with such broad empirical studies using field data.
} 
work was stated as the most important factor of acceptance. However, the location of the plant - only ranked $10^{\text {th }}$ of the 11 attributes for acceptance - was the most important argument to reject an offer. In general, however, the preferences between the two groups, who accept and reject the offer, differ only slightly except of the attribute "location”.

Boswell et al. (2003) examine the job choice process of about 100 college graduates and find similar results except that "location" plays a certain role also for accepting decisions in their study. Further on, they focus on the evaluation of interviews by the job seekers. Harris and Fink (1987) report explicit evidence that recruiter characteristics indeed have an impact on perceived job characteristics.

Much work has been done on sex differences in job attribute preferences. Konrad et al. (2000) discuss more than 200 examinations in their meta-analysis. The authors summarize that although differences are not dramatic they are consistent with typical gender roles so that rather males than females value earnings, whereas convenient working hours and commuting are more important for females. More recent studies suggest that family responsibilities may have an effect on job attribute preferences and career decisions (Konrad 2003, Konrad et al. 2005, Corrigall \& Konrad 2006). Results slightly differ across studies. Children in the household affect preferences to some extent for both men and women.

\section{Data and Methodology}

The data base of this examination is the German Socio-economic Panel (GSOEP), which is a large representative data set of people living in Germany. From the mid of the 1980s individuals are asked yearly and extensively about different aspects of life. The data are provided by the German Institute of Economic Research (DIW Berlin). ${ }^{2}$ In this study only employees are taken into account, who state that they changed their jobs during the last year and they quit their previous job. Therefore, this study focuses on employee initiated job changes to another firm. I make use of a 22 year period from 1985 to 2006. Employees of age 18 to 65 are taken into account. The resultant sample consists of 4,861 job changes.

The most important information for this study is that individuals are asked to compare their current with their previous job with respect to eight attributes: type of work, pay, chances of promotion, work load, commuting time, work hour regulations, fringe benefits and security

\footnotetext{
${ }^{2}$ Detailed information on the data and the questionnaire can be found at http://www.diw.de/english/soep/29012.html.
} 
against loss of job. For each attribute respondents have to state whether the new job improved or worsened the status or stayed about the same. ${ }^{3}$

First, it is possible to compare the fraction of improvements and declines between job attributes. Many improvements (few declines) are argued to hint for the importance of a certain attribute for employees. An underlying assumption therefore is that employees are not able to perfectly observe all job characteristics and eventually even do not know their preferences in detail especially at the beginning of their careers. Additionally, preferences may change over time or differ across groups of employees. Therefore, second, several subgroups of employees such as men and women, as well as West- and East-Germans are compared. The overall period of observation is divided into four sub-periods for some examinations: 1985-1990, 1991-1995, 1996-2000 and 2001-2006.

The attribute pay may be considered as a special case, since firms may have the policy to pay a kind of fixed mark-up to the previous wage so that a wage increase may result as an automatic by-product for job changes due to other reasons. Then there still remains the question why employees do not try to substitute an improvement in another attribute to wages, if the other attribute is supposed to be extremely important. One may also argue that wages would have increased also without job changes inside the firm, e.g. because of increased human capital (Becker 1962) or incentive reasons (Lazear 1979). However, extraordinary wage increases are usually attached to promotions inside a firm or inter-firm job changes. If there are no vacancies at a higher level of the hierrachy, employees have to quit and change the firm if they have pronounced preferences for pay. Although wages usually increase also inside over $\mathrm{t}$

I also make use of a multivariate analysis to simultaneously take several possible determinants of improvements of single attributes into consideration. Since the evaluation of the change in job attributes has an ordered three digit scale, an ordered probit estimate is used.

\section{Results}

The empirical results of this study are structured in three parts. First, I will focus on the change in the eight job attributes of the whole sample and subgroups with respect to gender,

\footnotetext{
${ }^{3}$ We have therefore three values of each variable and cannot analyze the magnitude of changes in attributes. In principle it would be possible to survey this for wages and commuting time, but less easy for other characteristics.
} 
region and observation period. Second, I provide a multivariate analysis of the data using ordered probit regressions and analyze several individual determinants of changes in job attributes. In a third step, I show that improvements in job attributes of repeated employee initiated job change are positively correlated.

\subsection{Changes in Job Attributes}

I will first give a general overview of the changes in the eight job attributes. Figure 1 indicates that considerable differences of the fraction of improvements and declines are observable. The attributes are listed by the fraction of improvements. Whereas nearly two of three individuals report an increased wage and more than half state an improved type of work, only one of three speaks of a better commuting time or work load. Therefore, the former seems to be more important for employees who change jobs. The fraction of individuals who do not report changes also differs across attributes. Some aspects such as wages and commuting time are easier to measure or to observe than others like chances of promotion or job security. ${ }^{4}$

--- insert Figure 1 about here ---

It is also interesting to have a look at the relation between the changes in job attributes. It is an empirical question, whether changes in job attributes are rather complements or substitutes. Changes of attributes in this study are somewhat positively correlated. However, the correlation coefficients of Spearman do not exceed 0.4 (see Table 1). There are also some significant negative correlations especially with respect to pay. Obviously, some individuals abstain from short commuting time for higher wages (or the other way around) which is in line with the idea of compensating differentials. The negative correlation between pay and work load is not surprising since some kind of career advancement usually lead both to higher wages and also to more responsible tasks with a higher work load. Other attributes such as type of work, chances of promotions and benefits are no substitutes for wages. Improvements of job attributes often go hand in hand. This finding indicates that some employees benefit more from job changes than others. These correlations only hint for differences between

\footnotetext{
${ }^{4}$ There is only information for the reason of employees' job quit for single years of the 1980s unfortunately. Not surprisingly there is some evidence that the fraction of improvements is somewhat higher for the subgroup of employees who quit their job and explicitly state that the reason was that they already have found a better job (Grund 2000).
} 
employees. However, individual employees may well balance job attributes of different job offers.

--- insert Table 1 about here ---

I now will have a look on subgroups of the sample with respect of gender and region. As stated above previous studies have found differences in job preferences between women and men. Due to German re-unification in 1990 and the following East German transformation process I also distinguish between East- and West-German employees.

In general there are two possibilities to analyze the data: First, improvements and declines can be compared across attributes for the whole sample or subgroups. Since the decision of quitting a job is supposed to be initiated by the employee, one can argue that a high fraction of improvements (a low fraction of declines) hints that a certain attribute is important for the decision. Therefore, I speak of an important attribute and a high general preference for it, when a high fraction of improvements is observed. Second, it is possible to compare subgroups of employees. Here, both absolute and relative differences across attributes can be examined. First, certain groups of employees may absolutely benefit from job changes on a larger scale. Second, the relative ranking of the importance of attributes can be compared across groups of employees. Whereas absolute differences in improvements of many attributes rather indicate differences in job opportunities, relative differences hint for different preferences. Then it is easy to rank order attributes for the whole sample and subgroups by using the difference between the fraction of improvements and declines as a measure for the importance of an attribute.

Table 2 indicates that especially pay and type of work are important for employees. In contrast, work load and commuting time are ranked least of the eight attributes. The column Whole sample of Table 2 corresponds to Figure 1. There are differences in ranks of the revealed preferences of men and women as well as for West- and East-Germans. Work hour regulations are relatively important for women (ranked $3^{\text {rd }}$ compared to $6^{\text {th }}$ by men), whereas promotion opportunities play a less important role for women (ranked only $5^{\text {th }}$ compared to $3^{\text {rd }}$ by men). At first glance, this may be explained by the fact that women still provide much more effort in child care. However, the ranks do not differ at all between women with or without minor children in the household so that gender roles are still relevant or future child 
care is already anticipated. Pay is dominated slightly by type of work in West Germany. In general, however, relative preferences are somewhat similar for gender and region, which is revealed by the rank correlation coefficient of Spearman ( 0.79 for gender ( $p=0.021), 0.95$ for region $(\mathrm{p}<0.001)$, $\mathrm{n}=8)$.

There are also absolute differences for gender and region. A Kolmogorov-Smirnov-test (K-Stest) for two independent samples is used to test these differences in the distribution of changes statistically. More improvements for men can be observed for chances of promotions and job security. In contrast women benefit more in terms of work hour regulations and commuting time. A comparison of West- and East-Germans indicates that more improvements are found in the Western part in general over the whole joint observation period from 1991 to 2006. Exceptions are pay and job security, where no differences can be found based on K-S-tests (Table 2).

--- insert Table 2 about here ---

It is interesting to have a closer look on these differences. The whole period of time is divided into four sub periods (see Table 3). It turns out that the differences are present in the first years after unification in the period 1991 to 1995. The level of significance already diminishes during the second half of the 1990s. From the year 2000 on hardly any differences between West- and East-Germans can be observed any more. In this sense the adaption process of the formerly centrally planned East-German economy seems to be completed in terms of employees' improvements at job changes.

The ranks of the job attributes are pretty stable in both West-Germany and East-Germany. The bivariate rank correlations between time periods are rather high for West-Germany $(0.826$ to 0.952 ) as well as for East-Germany (0.762 to 0.833) and highly significant. Figure A1 in the appendix gives a more detailed overview of actual fractions of improvements and declines by job attribute, period of time and region.

There are also considerable differences with respect to other individual characteristics. For example, university graduates state more improvements with respect to promotion chances (0.52), but less with respect to working hours regulation (0.38) and work load (0.29). Furthermore, young employees up to 40 years state more improvements in general than the 
elderly (see Table A1 in the appendix). Therefore, it seems reasonable to explore possible determinants of improvements within a multivariate analysis in some more detail. This is provided within the following subsection.

In contrast to previous studies these results are based on actual job change behaviour and (perceived) changes in job attributes. Still we have to keep in mind that the data are restricted to available job alternatives. If higher pay is an automatic by product of a job change, the results may not always reflect preferences.

--- insert Table 3 about here ---

\subsection{Determinants of changes in job attributes}

Some further possible determinants of improvements in the eight job attributes are taken into account next to sex, region and the year of the job change. Preferences may depend on the age of the employee and also the education of individuals may affect both preferences and possibility to get certain job offers (Corrigal \& Konrad 2006). Education is measured by years of schooling, which represents the usually necessary number of years for a certain degree up to a maximum of 18 for a university masters degree. Some individuals do not receive any degree, which is coded with a hypothetical value of 7 years. Table 4 provides descriptive statistics of these variables. People, who quit and change jobs are somewhat younger and better educated than the whole German workforce.

--- insert Table 4 about here ---

These characteristics are used as independent variables in a multivariate examination. Changes in job attributes act as dependent variables in the regressions. The change can take three values: An improvement is coded with a " 1 ”, no change with a " 0 " and a decline with a “-1”. We therefore have an ordered scale so that an ordered probit approach is used. Table 5a shows the corresponding results with the eight job attributes as dependent variables. 
The results confirm that there are indeed some differences with respect to age. Male employees have higher probabilities of improvements for the type of work, pay and chances of promotions. In contrast women benefit more in terms of commuting time and work hour regulations. Younger employees gain more from job changes in general. This is true in particular for type of work, pay and chances of promotions. At least two aspects have to be taken into account for the comparison of West- and East-Germany: First, the East-German economy has been transformed following the re-unification of both German parts in 1990 . Second, the economic situation remained much worse in East-Germany until the end of the observation period. The East-German unemployment rate is almost twice the amount of WestGermany (e.g. 0.19 compared to 0.1 in the year 2006). Considering the total observation period, West German employees gain more from quitting. As already documented in Table 3 and confirmed in regressions of sub periods (see Table A2a and b in the appendix) this effect is driven by the early years and diminishes over time, such that there are hardly any differences in the 2000s.

One might expect that well educated employees with a high schooling degree face significant more improvements. This is true at least with respect to type of work, pay and promotion chances because of better career opportunities in developed countries. A negative effect is found for the probabilities with respect to work load, commuting time and work hour regulations, though.

There are not many pronounced differences for marital status and between employees with and without minor children. Surprisingly, employees with children state even slightly less improvements with respect to work load and commuting time.

It may be the case that an improvement in a certain job attribute is only some kind of automatic by-product of a job change, but has no relevance for employees' utility. A general possibility to measure utility from work is to use individuals' general job satisfaction. Job satisfaction is captured in the GSOEP on an 11-digit scale from 0 (totally unsatisfied) to 10 (totally satisfied) with a mean of 7.39 and a standard deviation of 2.04 in this sample. Improvements in all job attributes except of commuting time ${ }^{5}$ are positively associated with job satisfaction indicated in an ordered probit regression approach, which hints that improvement in job characteristics are indeed relevant for employees (see Table A3 in the

\footnotetext{
${ }^{5}$ Commuting time may not be directly associated to work. Matiaske and Mellewigt (2001) provide more detailed evidence on the determinants of job satisfaction in Germany.
} 
appendix). This indicates that employees being dissatisfied with certain important job attributes will intent to quit. Therefore, Skalli et al. (2008) suggest that human resource management is supposed to focus on employees' satisfaction with the relevant facets of a job rather than overall job satisfaction. They point out country differences and reveal that satisfactions with earnings and type of work have the largest impact on overall job satisfaction in most European countries. Hence, the results are in line with the evidence at hand. They do not examine turnover (intentions), though.

One can argue that using the specification of Table 5a rather job opportunities than job preferences are examined, because certain groups of employees may face better alternatives and therefore more improvements in general. In Table 5a I do not control for changes in other job attributes. Overall improvements are analyzed in model (9). There I calculate the measure sum of changes by the sum of the eight changes in job attributes assigning a " 1 " for each increase and a “-1” for each decline. On average employees face more improvements than declines. The mean of sum of changes is 2.29 with a standard deviation of 2.71. More improvements can be observed rather for male and younger employees from West-Germany over the whole observation period.

Table 5b replicates the regressions of Table 5a with the exception that changes in other job attributes are controlled for integrating two dummy variables for each attribute. ${ }^{6}$ Doing this, rather relative job preferences for a certain attribute then job opportunities are examined. In this sense the set of dummy variables acts as a proxy for overall job opportunities. Some results remain the same. For instance, male face fewer improvements concerning work hour regulations and East-German employees face fewer improvements with respect to the work load, chances of promotions and type of work. However, several significances concerning commuting time, work hour regulations and job securities disappear. Controlling for changes in other attributes, improvements concerning type of work can rather be observed for male and educated employees.

--- insert Table 5b about here ---

\footnotetext{
${ }^{6}$ Due to space limitations the results for the job attribute dummies are not presented. In general the results confirm the bivariate correlations of Table 1 . Pseudo- $\mathrm{R}^{2} \mathrm{~s}$ considerably increase. The results are robust with respect to another specification integrating the sum of changes of the seven other attributes instead of the set of dummy variables in the regression.
} 


\subsection{Repeated Employee Initiated Job Changes}

Several employees do not quit a job just once in their occupational career but more than one time. There are 1,367 observations in the sample, for which there is information for a previous job change. It is now interesting to analyze, whether improvements and declines positively correlate from job change to job change or whether abstaining from an improvement at a certain job change will lead to a future improvement. Therefore, Table 6 presents simple bivariate correlations between the current and the previous job change for the eight attributes. It turns out, that correlations are positive for all characteristics so that a temporary refrainment with respect to certain attributes does not seem to play a decisive role here. Correlations are not perfect, though. Over half of employees with declines concerning type of work and pay at the previous job change face an improvement at the current one.

--- insert Table 6 about here ---

\section{Discussion and Conclusion}

This empirical study offers a new approach of examining job preferences of employees. Subsequent to employee initiated job changes, individuals state improvements and declines of their new job compared to the former one with respect to eight job attributes. Most improvements are observed for pay and type of work so that these job characteristics are argued to be the most important ones for job changes. This information is important for firms' recruiting and retention policy.

This study is limited to eight job attributes. It may well be the case that other characteristics such as the relationship to co-workers and supervisors or the image of the company are also important or even more important attributes. In his seminal study, Jurgensen (1978) also considers these characteristics. Individuals report a higher preference for these attributes than for work load and work hour regulation, for instance. However, they ascribe others only low preferences for co-workers, supervisors and the company (see Table 7). Slaughter et al. (2006) extend the analysis to 14 attributes considering the work organization in a more detailed way, but neglecting job security and fringe benefits. They ask students and both conduct a direct estimation by asking three different questions as well as a policy capturing approach. Results include that co-workers and supervisors are also somewhat important for 
individuals. Rank correlations of attributes between the two methods are quite substantial but not perfect. Pay is found to be the most import job attribute. This is also the result of Jurgensen's study for the ascribed preferences to others, but pay is only ranked $5^{\text {th }}$ stating own preferences $^{7}$ which suggests socially desirable answers. The results of the study at hand are also positively correlated to the other studies in spite of differences in the observation period, the country and the method. Rank correlation is perfect to the study by Slaughter and coauthors. There are only five congruent attributes though. Compared to Jurgensen's study my results are more correlated with respect to the preferences ascribed to others. I already refer to the study by Skalli et al. (2008) on the effect of facets of job satisfaction on overall job satisfaction above (section 5.2). Indeed, the ranks of the five common attributes are somewhat (but nor perfect) correlated indicating that it is worth examining real world decisions of employees next to traditional kind of questionings.

--- insert Table 7 about here ---

I do not analyze the selection process of employees to jobs in this study. For sure, employees do not randomly select to jobs. That is why observed preferences may deviate across industries and firm size categories. Based on a questioning of about 200 individuals, Karl and Sutton (1998) also find some differences between private and public sector employees. Private sector workers state the highest value on good wages whereas public sector employees value an interesting work the most. Since I do not want to mix up individual differences and selection on jobs in this study, I abstain from integrating firm characteristics to this study.

An underlying assumption of this study is that individuals' expectations about new jobs are not systematically biased. An interesting issue for future research is whether this is true or whether expectations with respect to certain attributes are too optimistic or pessimistic. A job as a whole may be characterized as a search good with regard to some attributes but as experience good with regard to others. Additionally, it seems to be interesting to examine the interplay of job characteristics and changes in preferences by following individuals over their whole working life.

\footnotetext{
${ }^{7}$ This is in line with other direct estimations of job preferences such as the international study by Corrigal and Konrad (2006).
} 


\section{References}

Becker, G. S. [1962], “Investment in Human Capital: A Theoretical Analysis,” Journal of Political Economy, 70, 9-49.

Benabou, R., \& Tirole, J. (2006). Incentives and prosocial behavior, American Economic Review, 96, 1652-1678.

Biddle, J. E., \& Zarkin, G. A. (1988). Worker preferences and market compensation for job risk. The Review of Economics and Statistics, 70, 660-667.

Bolton, G. E., \& Ockenfels, A. (2000). ERC: A theory of equity, reciprocity, and competition. American Economic Review, 90, 166-183.

Boswell, W. R., Roehling, M.V., LePine M.A., \& Moynihan, L.M. (2003). Individual jobchoice decisions and the impact of job attributes and recruitment practices: A longitudinal field study. Human Resource Management, 42, 23-37.

Bretz, R. D., \& Judge, T.A. (1994). The role of human resources systems in job applicant decision processes. Journal of Management, 20, 531-551.

Corrigall, E.A., \& Konrad A.M. (2006). The relationship of job attribute preferences to employment, hours of paid work, and family responsibilities: An analysis comparing women and men. Sex Roles, 54, 95-111.

Falk, A., Fehr E.; \& Fischbacher, U. (2008). Testing theories of fairness - intentions matter. Games and Economic Behavior, 62, 287-303.

Farber, H. S. (2008). Reference-dependent preferences and labor supply: The case of New York City taxi drivers. American Economic Review, 98, 1069-1082.

Fehr, E., \& Schmidt, K.M. (1999). A theory of fairness, competition, and cooperation. The Quarterly Journal of Economics 114, 817-868.

Grund, C. (2000). Prospect theorie, Mobilitätshemmnisse und Kündigungen von Arbeitnehmern. Kossbiel, H. (Ed.): Modellgestützte Personalentscheidungen, 4, 73-93.

Grund, C. (2003). Arbeitsplatzpräferenzen und Besitzeffekte. Zeitschrift für Personalforschung, 17, 87-109.

Grusky, D. B. (1994). Social Stratification. Boulder: Westview.

Hardie, B. G. S., Johnson, E. J., \& Fader, P. S. (1993). Modeling loss aversion and reference dependence effects on brand choice. Marketing Science, 12, 378-394.

Harris, M. M., \& Fink, L. S. (1987). A field study of applicant reactions to employment opportunities: Does the recruiter make a difference? Personnel Psychology, 40, 765784.

Huber, G. P., Daneshgar, R., \& Ford D. L. (1971). An empirical comparison of five utility models for predicting job preferences. Organizational Behavior and Human Performance, 6, 267-282.

Jurgensen, C. E. (1978). Job preferences (what makes a job good or bad)? Journal of Applied Psychology, 63, 267-276.

Kahneman, D., \& Tversky, A. (1979). Prospect theory: An analysis of decision under risk. Econometrica, 47, 1225-1244.

Karl, K. A., \& Sutton, C. L. (1998). Job values in today's workforce: A comparison of public and private sector employees. Public Personnel Management, 27, 515-527. 
Karren, R. J., \& Woodard Barringer, M. (2002). A review and analysis of the policy-capturing methodology in organizational research: Guidelines for research and practice. Organizational Research Methods, 5, 337-361.

Konrad, A. M. (2003). Family Demands and Job Attribute Preferences: A 4-Year Longitudinal Study of Women and Men. Sex Roles, 49, 35-46.

Konrad, A. M., Ritchie, J.E., Lieb, P., \& Corrigall, E. (2000). Sex differences and similarities in job attribute preferences: A meta-analysis. Psychological Bulletin 126, 593-641.

Konrad, A. M., Yang, Y., Goldberg, C., \& Sullivan, S. E. (2005). Preferences for Job Attributes Associated with Work and Family: A Longitudinal Study of Career Outcomes. Sex Roles, 53, 303-315.

Lazear, E. P. (1979), “Why is there Mandatory Retirement?” Journal of Political Economy, 87, 1261-1284.

Matiaske, W., Mellewigt, T. (2001). Arbeitszufriedenheit: Quo vadis? Eine Längsschnittuntersuchung zu Determinanten von Arbeitszufriedenheit. Die Betriebswirtschaft, 61, 7-24.

Mortensen, D. T. (1970). Job search, the duration of unemployment, and the phillips curve. American Economic Review, 60, 847-862.

Osborn, D.P. (1990). A reexamination of the organizational choice process. Journal of Vocational Behavior, 36, 45-60.

Payne, J.W., Bettman, J.R., \&Johnson, E.D. (1993). The adaptive decision maker. New York: Cambridge University Press.

Powell, G. N. (1984). Effect of job attributes and recruiting practices on applicant decisions: A comparison. Personnel Psychology, 37, 721-732.

Rynes, S. L. (1991). Recruitment, job choice, and post-hire consequences: A call for new research directions. In M. D. Dunnette \& L. M. Hough (Eds.), Handbook of industrial and organizational psychology (pp. 399-444). Palo Alto, CA: Consulting Psychologists Press.

Rynes, S. L., Schwab, D.P., \& Heneman, H.G. (1983). The role of pay and market pay variability in job application decisions. Organizational Behavior and Human Decision Processes, 31, 353-364.

Skalli, A., Theodossiou, I., \& Vasileiou, E. (2008). Jobs as Lancaster goods: Facets of job satisfaction and overall job satisfaction. Journal of Socio-Economics, 37, 1906-1920.

Slaughter, J. E., Richard, E. M., \& Martin, J. M. (2006). Comparing the Efficacy of PolicyCapturing Weights and Direct Estimates for Predicting Job Choice. Organizational Research Methods, 9, 285- 314.

Sliwka, D. (2007). Trust as a signal of a social norm and the hidden costs of incentive schemes. American Economic Review, 97, 999-1012.

Smith, A. (1976): An Inquiry into the Nature and Causes of the Wealth of Nations. Munich.

Stigler, G. J. (1961). The economics of information. Journal of Political Economy, 69, 213225.

Stigler, G. J. (1962). Information in the labor market. Journal of Political Economy, 70, 94105.

Thaler, R. H. (1980). Toward a positive theory of consumer choice. Journal of Economic Behavior \& Organization, 1, 39-60. 
Turban, D.B., Eyring, A.E., \&. Campion, J.E (1993). Job attributes: Preferences compared with reasons for accepting and rejecting job offers. Journal of Occupational and Organizational Psychology, 66, 71-81.

Tversky, A. (1972). Elimination by aspects: A theory of choice. Psychological Review, 79, 281-299.

Von Neumann, J., \& Morgenstern, O. (1953). Theory of games and economic behavior. New Jersey: Princeton University Press.

Vroom, V. H. (1966). Organizational choice: A study of pre- and postdecision processes. Organizational Behavior and Human Decision Processes, 1, 212-225.

Wanous, J. P., Keon, T. L., \& Latack, J. C. (1983). Expectancy theory and occupational/organizational choices: A review and test. Organizational Behavior and Human Decision Processes, 32, 66-86.

Zedeck, S. (1977). An information processing model and approach to the study of motivation. Organizational Behavior and Human Performance, 18, 47-77. 


\section{Figures and Tables}

Figure 1: Fraction of Improvements and Declines by Job Characteristic

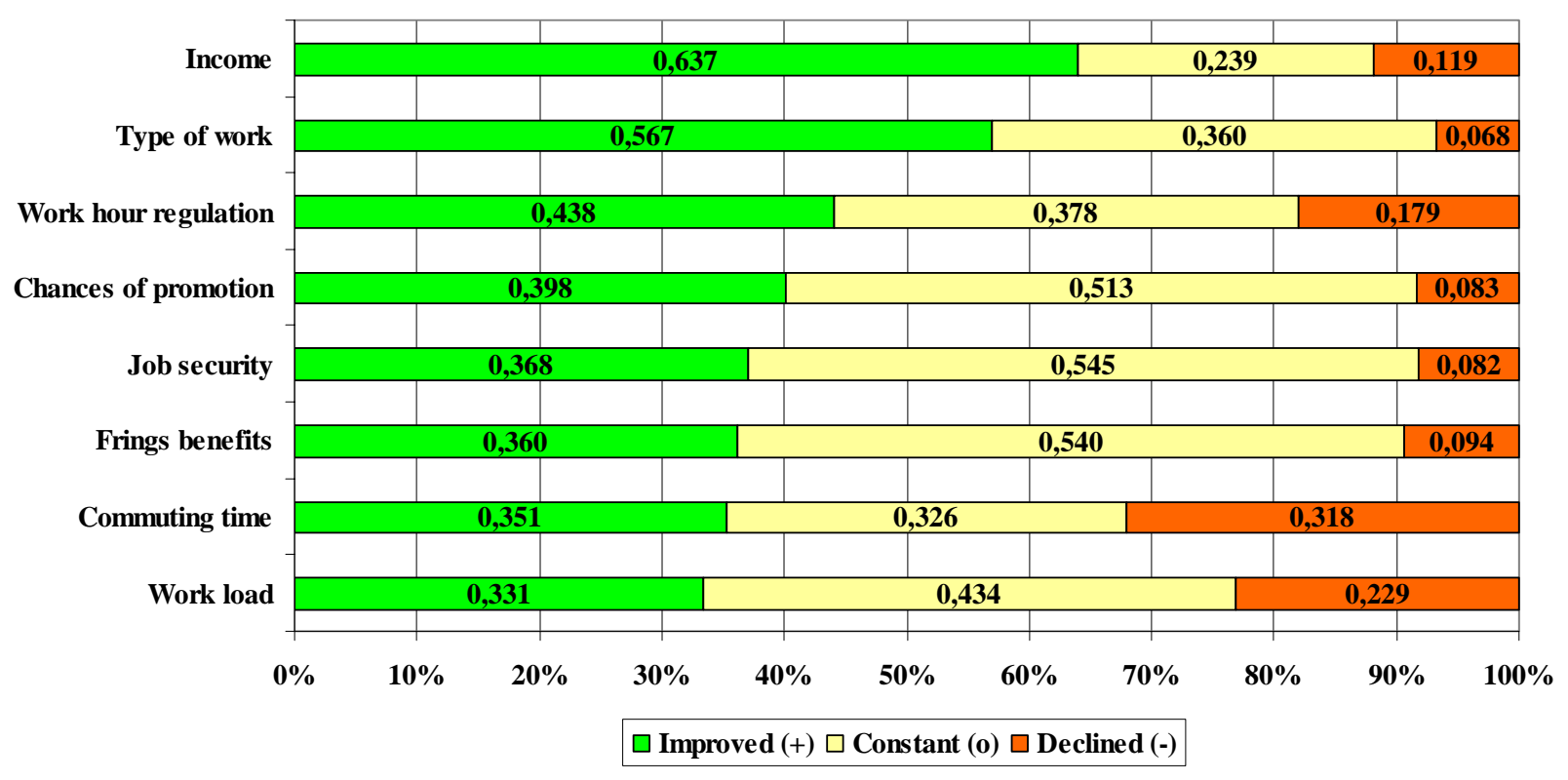


Table 1: Correlation matrix of Comparison of Job Characteristics

\begin{tabular}{|c|c|c|c|c|c|c|c|c|}
\hline & (1) & (2) & (3) & (4) & (5) & (6) & (7) & (8) \\
\hline (1) Type of work & 1 & & & & & & & \\
\hline (2) Pay & $0,152 * * *$ & 1 & & & & & & \\
\hline (3) Chances of promotion & $0,319 * * *$ & $0.267 * * *$ & 1 & & & & & \\
\hline (4) Work load & $0,175 * * *$ & $-0,072 * * *$ & 0,018 & 1 & & & & \\
\hline (5) Commuting time & 0,018 & $-0,074 * * *$ & $-0,053 * * *$ & $0,137 * * *$ & 1 & & & \\
\hline (6) Work hour regulation & $0,114^{* * *}$ & $-0,014$ & $0,040 * *$ & $0,368 * * *$ & $0,186 * * *$ & 1 & & \\
\hline (7) Frings benefits & $0,166^{* * *}$ & $0,243^{* * *}$ & $0,229 * * *$ & $0,171^{* * *}$ & 0,015 & $0,256^{* * *}$ & 1 & \\
\hline (8) Job security & $0,198 * * *$ & $0,116^{* * *}$ & $0,240 * * *$ & $0,148 * * *$ & 0,021 & $0,162 * * *$ & $0,390 * * *$ & 1 \\
\hline
\end{tabular}

Notes: Bivariate Spearman rank correlation coefficients are presented. *** significant at 0,01 level, ** significant at 0,05 level, * significant at 0,1 level. 
Table 2: Improvements and declines of job attributes by subgroups - rank in parantheses (criterion: fraction improvements - fraction declines)

\begin{tabular}{|c|c|c|c|c|c|c|c|c|c|c|c|c|c|c|}
\hline & & $\begin{array}{c}\text { Wh } \\
\text { sam } \\
(n=48\end{array}$ & & $\begin{array}{r}M e \\
(n=28\end{array}$ & 85) & $\begin{array}{l}\text { Won } \\
(n=19\end{array}$ & 1en & $\begin{array}{l}\text { K-S-Test } \\
\text { (sex) }\end{array}$ & & $\begin{array}{r}W \\
(n=3\end{array}$ & st & $\begin{array}{c}E a \\
(n=c\end{array}$ & & $\begin{array}{c}\text { K-S-Test } \\
\text { (region) }\end{array}$ \\
\hline & - & 0.119 & & 0.110 & & 0.134 & & & - & 0.118 & & 0.126 & & \\
\hline Pay & $\mathbf{0}$ & 0.240 & [1] & 0.240 & [1] & 0.241 & [1] & n. s. & $\mathbf{0}$ & 0.242 & [2] & 0.233 & [1] & n. s. \\
\hline & + & 0.640 & & 0.651 & & 0.625 & & & + & 0.640 & & 0.641 & & \\
\hline & - & 0.068 & & 0.058 & & 0.083 & & & - & 0.066 & & 0.078 & & \\
\hline Type of work & $\mathbf{0}$ & 0.362 & [2] & 0.357 & [2] & 0.369 & [2] & $*$ & $\mathbf{0}$ & 0.339 & [1] & 0.463 & [2] & $* * *$ \\
\hline & + & 0.570 & & 0.585 & & 0.548 & & & + & 0.595 & & 0.459 & & \\
\hline & - & 0.083 & & 0.074 & & 0.098 & & & - & 0.078 & & 0.106 & & \\
\hline Chances of promotion & $\mathbf{0}$ & 0.516 & [3] & 0.496 & [3] & 0.546 & [5] & $* * *$ & $\mathbf{0}$ & 0.505 & [3] & 0.565 & [4] & $* * *$ \\
\hline & + & 0.401 & & 0.431 & & 0.356 & & & + & 0.417 & & 0.328 & & \\
\hline & - & 0.082 & & 0.073 & & 0.096 & & & - & 0.077 & & 0.108 & & \\
\hline Job security & $\mathbf{0}$ & 0.548 & [4] & 0.537 & [4] & 0.564 & [6] & $* * *$ & $\mathbf{0}$ & 0.546 & [4] & 0.557 & [3] & n. s. \\
\hline & + & 0.370 & & 0.390 & & 0.341 & & & + & 0.378 & & 0.336 & & \\
\hline & - & 0.094 & & 0.094 & & 0.096 & & & - & 0.084 & & 0.139 & & \\
\hline Fringe benefits & $\mathbf{0}$ & 0.543 & [5] & 0.544 & [5] & 0.542 & [4] & n. s. & $\mathbf{0}$ & 0.542 & [5] & 0.548 & [5] & $* * *$. \\
\hline & + & 0.362 & & 0.362 & & 0.363 & & & + & 0.373 & & 0.314 & & \\
\hline & - & 0.180 & & 0.184 & & 0.174 & & & - & 0.173 & & 0.210 & & \\
\hline Work hours regulations & 0 & 0.380 & [6] & 0.412 & [6] & 0.332 & [3] & $* * *$ & $\mathbf{0}$ & 0.372 & [6] & 0.412 & [6] & $* * *$ \\
\hline & + & 0.440 & & 0.404 & & 0.494 & & & + & 0.454 & & 0.378 & & \\
\hline & - & 0.231 & & 0.232 & & 0.229 & & & - & 0.217 & & 0.291 & & \\
\hline Work load & 0 & 0.436 & [7] & 0.445 & [7] & 0.422 & [7] & n. s. & 0 & 0.426 & [7] & 0.478 & [7] & $* * *$ \\
\hline & + & 0.333 & & 0.323 & & 0.349 & & & + & 0.357 & & 0.232 & & \\
\hline & - & 0.320 & & 0.334 & & 0.299 & & & - & 0.311 & & 0.358 & & \\
\hline Commuting time & 0 & 0.328 & [8] & 0.332 & [8] & 0.321 & [8] & ** & 0 & 0.323 & [8] & 0.346 & [8] & $* * *$ \\
\hline & + & 0.353 & & 0.334 & & 0.379 & & & + & 0.365 & & 0.296 & & \\
\hline
\end{tabular}

Notes: K-S-Tests indicate Kolmogorov-Smirnov tests of identical distributions of changes in job attributes of sex and region: * significant at $10 \%$, ** significant at $5 \%, * * *$ significant at $1 \%$, n. s. = not significant. 
Table 3: Ranks of job attributes by region and period (criterion: fraction improvements - fraction declines) and differences in changes of job attributes between West- und East-Germany by period of time

\begin{tabular}{|c|c|c|c|c|c|c|c|c|c|c|}
\hline & \multicolumn{4}{|c|}{ West Germany } & \multicolumn{3}{|c|}{ East Germany } & \multicolumn{3}{|c|}{ K-S-Test (West vs. East) } \\
\hline & $\begin{array}{c}1985- \\
1990 \\
\end{array}$ & $\begin{array}{c}1991- \\
1995 \\
\end{array}$ & $\begin{array}{c}1996- \\
2000 \\
\end{array}$ & $\begin{array}{c}2001- \\
2006 \\
\end{array}$ & $\begin{array}{c}1991- \\
1995 \\
\end{array}$ & $\begin{array}{c}1996- \\
2000 \\
\end{array}$ & $\begin{array}{c}2001- \\
2006 \\
\end{array}$ & $\begin{array}{c}1991- \\
1995 \\
\end{array}$ & $\begin{array}{c}1996- \\
2000 \\
\end{array}$ & $\begin{array}{c}2001- \\
2006 \\
\end{array}$ \\
\hline Pay & 1 & 1 & 2 & 2 & 1 & 1 & 1 & n. s. & n. s. & n. s. \\
\hline Type of work & 2 & 2 & 1 & 1 & 2 & 2 & 2 & $* * *$ & $* * *$ & $*$ \\
\hline Chances of promotion & $4=$ & 3 & 3 & 3 & 4 & 4 & 5 & $* * *$ & $* *$ & n. s. \\
\hline Job security & 3 & 4 & 4 & 6 & 3 & 5 & 6 & n. s. & $* * *$ & n. s. \\
\hline Fringe benefits & $4=$ & 6 & 5 & 4 & 5 & 6 & 3 & $* *$ & n. s. & n. s. \\
\hline Work hours regulations & 6 & 5 & 6 & 5 & 6 & 3 & 4 & $* * *$ & n. s. & n. s. \\
\hline Work load & 7 & 7 & 7 & 7 & 7 & 7 & 8 & $* * *$ & $* * *$ & n. s. \\
\hline Commuting time & 8 & 8 & 8 & 8 & 8 & 8 & 7 & $* * *$ & n. s. & n. s. \\
\hline
\end{tabular}

Notes: K-S-Tests indicate Kolmogorov-Smirnov tests of identical distributions of changes in job attributes across regions: * significant at 10\%, ** significant at $5 \%$, *** significant at $1 \%$, $\mathrm{n}$.s.: not significant. 
Table 4: Descriptive Statistics $(n=4,681)$

\begin{tabular}{|lcccc|}
\hline & $\begin{array}{c}\text { Mean } \\
\text { (Share) }\end{array}$ & $\begin{array}{c}\text { Standard } \\
\text { deviation }\end{array}$ & Min & Max \\
\hline Sex (Male=1, Female=0) & 0.593 & & 0 & 1 \\
Region (West=1, East=0) & 0.814 & & 0 & 1 \\
Age & 32.92 & 8.67 & 18 & 62 \\
Years of Schooling & 11.96 & 2.60 & 7 & 18 \\
Minor child in household (Yes=1) & 0.436 & & 0 & 1 \\
Married Marital status & & & 0 & 1 \\
Separated, divorced, widowed & 0.521 & & 0 & 1 \\
Single & 0.100 & & 0 & 1 \\
\hline
\end{tabular}


Table 5a: Determinants of Improvements without Controls for Changes in Other Attributes

(Ordered Probit Model, $-1=$ declined, $0=$ constant, $1=$ improved)

\begin{tabular}{|c|c|c|c|c|c|c|c|c|c|}
\hline & $\begin{array}{c}\text { (1) } \\
\text { Type of } \\
\text { work }\end{array}$ & $\begin{array}{l}\text { (2) } \\
\text { Pay }\end{array}$ & $\begin{array}{l}\text { (3) } \\
\text { Chances of } \\
\text { promotion }\end{array}$ & $\begin{array}{c}\text { (4) } \\
\text { Work } \\
\text { Load }\end{array}$ & $\begin{array}{c}\text { (5) } \\
\text { Commuting } \\
\text { time }\end{array}$ & $\begin{array}{l}\quad(6) \\
\text { Work hour } \\
\text { regulation }\end{array}$ & $\begin{array}{c}\text { (7) } \\
\text { Fringe } \\
\text { benefits }\end{array}$ & $\begin{array}{c}(8) \\
\text { Job } \\
\text { security }\end{array}$ & $\begin{array}{c}\text { (9) } \\
\text { Sum of } \\
\text { changes }\end{array}$ \\
\hline Sex $($ Male=1) & $\begin{array}{c}0.143^{* * *} \\
(0.036)\end{array}$ & $\begin{array}{l}0.091 * * \\
(0.037)\end{array}$ & $\begin{array}{c}0.220 * * * \\
(0.035)\end{array}$ & $\begin{array}{l}-0.010 \\
(0.034)\end{array}$ & $\begin{array}{c}-0.086 * * \\
(0.034)\end{array}$ & $\begin{array}{c}-0.152 * * * \\
(0.035)\end{array}$ & $\begin{array}{c}0.023 \\
(0.034)\end{array}$ & $\begin{array}{c}0.136 * * * \\
(0.035)\end{array}$ & $\begin{array}{c}0.059 * * \\
(0.030)\end{array}$ \\
\hline Age & $\begin{array}{c}-0.005^{* *} \\
(0.002)\end{array}$ & $\begin{array}{c}-0.012 * * * \\
(0.003)\end{array}$ & $\begin{array}{c}-0.015^{* * *} \\
(0.002)\end{array}$ & $\begin{array}{c}-0.007 * * * \\
(0.002)\end{array}$ & $\begin{array}{l}-0.002 \\
(0.002)\end{array}$ & $\begin{array}{c}-0.008 * * * \\
(0.002)\end{array}$ & $\begin{array}{c}-0.007 * * * \\
(0.002)\end{array}$ & $\begin{array}{c}-0.008 * * * \\
(0.002)\end{array}$ & $\begin{array}{c}-0.014 * * * \\
(0.002)\end{array}$ \\
\hline Region (West=1) & $\begin{array}{c}0.280 * * * \\
(0.045)\end{array}$ & $\begin{array}{c}-0.014 \\
(0.049)\end{array}$ & $\begin{array}{c}0.243^{* * *} \\
(0.046)\end{array}$ & $\begin{array}{c}0.200 * * * \\
(0.043)\end{array}$ & $\begin{array}{c}0.100 * * \\
(0.044)\end{array}$ & $\begin{array}{c}0.108 * * \\
(0.044)\end{array}$ & $\begin{array}{c}0.147 * * * \\
(0.046)\end{array}$ & $\begin{array}{c}0.130 * * * \\
(0.046)\end{array}$ & $\begin{array}{c}0.260 * * * \\
(0.040)\end{array}$ \\
\hline Years of Schooling & $\begin{array}{c}0.027 * * * \\
(0.007)\end{array}$ & $\begin{array}{c}0.024^{* * *} \\
(0.007)\end{array}$ & $\begin{array}{c}0.062 * * * \\
(0.007)\end{array}$ & $\begin{array}{c}-0.040 * * * \\
(0.007)\end{array}$ & $\begin{array}{c}-0.016 * * \\
(0.007)\end{array}$ & $\begin{array}{c}-0.017^{* *} \\
(0.007)\end{array}$ & $\begin{array}{c}-0.014^{* *} \\
(0.007)\end{array}$ & $\begin{array}{c}-0.008 \\
(0.007)\end{array}$ & $\begin{array}{c}-0.001 \\
(0.006)\end{array}$ \\
\hline \multicolumn{10}{|l|}{ Marital status (base: married): } \\
\hline Separated, divorced, widowed & $\begin{array}{c}0.012 \\
(0.060)\end{array}$ & $\begin{array}{c}0.136 * * \\
(0.063)\end{array}$ & $\begin{array}{c}0.005 \\
(0.058)\end{array}$ & $\begin{array}{c}-0.169 * * * \\
(0.057)\end{array}$ & $\begin{array}{c}-0.038 \\
(0.057)\end{array}$ & $\begin{array}{c}-0.106 * \\
(0.057)\end{array}$ & $\begin{array}{c}0.006 \\
(0.057)\end{array}$ & $\begin{array}{c}-0.070 \\
(0.058)\end{array}$ & $\begin{array}{c}-0.058 \\
(0.052)\end{array}$ \\
\hline Single & $\begin{array}{l}0.009 \\
(0.050)\end{array}$ & $\begin{array}{c}0.016 \\
(0.052)\end{array}$ & $\begin{array}{l}-0.040 \\
(0.049)\end{array}$ & $\begin{array}{c}-0.086^{*} \\
(0.047)\end{array}$ & $\begin{array}{l}-0.059 \\
(0.047)\end{array}$ & $\begin{array}{l}-0.044 \\
(0.047)\end{array}$ & $\begin{array}{l}-0.063 \\
(0.048)\end{array}$ & $\begin{array}{c}-0.098 * * \\
(0.049)\end{array}$ & $\begin{array}{l}-0.083 * \\
(0.043)\end{array}$ \\
\hline Children in household (yes=1) & $\begin{array}{c}0.009 \\
(0.040)\end{array}$ & $\begin{array}{l}-0.008 \\
(0.041)\end{array}$ & $\begin{array}{l}-0.053 \\
(0.038)\end{array}$ & $\begin{array}{c}-0.074^{* *} \\
(0.038)\end{array}$ & $\begin{array}{c}-0.064^{*} \\
(0.038)\end{array}$ & $\begin{array}{c}0.023 \\
(0.038)\end{array}$ & $\begin{array}{c}0.005 \\
(0.038)\end{array}$ & $\begin{array}{c}0.031 \\
(0.039)\end{array}$ & $\begin{array}{c}-0.033 \\
(0.035)\end{array}$ \\
\hline Year (22 dummies) & Yes & Yes & Yes & Yes & Yes & Yes & Yes & Yes & Yes \\
\hline $\begin{array}{l}\text { Control for changes in other } \\
\text { attributes ( } 7 * 2 \text { dummies) }\end{array}$ & No & No & No & No & No & No & No & No & No \\
\hline \# Observations & 4,861 & 4,861 & 4,861 & 4,861 & 4,861 & 4,861 & 4,861 & 4,861 & 4,861 \\
\hline Pseudo-R² & 0.013 & 0.016 & 0.026 & 0.014 & 0.006 & 0.006 & 0.008 & 0.009 & 0.010 \\
\hline
\end{tabular}

Notes: Robust standard errors in parantheses. * significant at $10 \%, * *$ significant at $5 \%, * * *$ significant at $1 \%$ 
Table 5b: Determinants of Improvements with Controls for Changes in Other Attributes

(Ordered Probit Model, -1=declined, $0=$ constant, $1=$ improved))

\begin{tabular}{|c|c|c|c|c|c|c|c|c|}
\hline & $\begin{array}{c}\text { (1) } \\
\text { Type of } \\
\text { work }\end{array}$ & $\begin{array}{l}\text { (2) } \\
\text { Pay }\end{array}$ & $\begin{array}{l}\text { (3) } \\
\text { Chances of } \\
\text { promotion }\end{array}$ & $\begin{array}{c}(4) \\
\text { Work } \\
\text { Load }\end{array}$ & $\begin{array}{c}\text { (5) } \\
\text { Commuting } \\
\text { time }\end{array}$ & $\begin{array}{l}\quad(6) \\
\text { Work hour } \\
\text { regulation }\end{array}$ & $\begin{array}{c}\text { (7) } \\
\text { Fringe } \\
\text { benefits }\end{array}$ & $\begin{array}{c}\text { (8) } \\
\text { Job } \\
\text { security }\end{array}$ \\
\hline Sex (Male=1) & $\begin{array}{l}0.084 * * \\
(0.037)\end{array}$ & $\begin{array}{c}0.015 \\
(0.038)\end{array}$ & $\begin{array}{c}0.163 * * * \\
(0.036)\end{array}$ & $\begin{array}{c}0.031 \\
(0.035)\end{array}$ & $\begin{array}{l}-0.051 \\
(0.034)\end{array}$ & $\begin{array}{c}-0.163^{* * *} \\
(0.036)\end{array}$ & $\begin{array}{l}-0.023 \\
(0.036)\end{array}$ & $\begin{array}{c}0.110 * * * \\
(0.036)\end{array}$ \\
\hline Age & $\begin{array}{c}0.002 \\
(0.003)\end{array}$ & $\begin{array}{c}-0.010 * * * \\
(0.003)\end{array}$ & $\begin{array}{c}-0.012^{* * *} \\
(0.002)\end{array}$ & $\begin{array}{c}-0.006 * * * \\
(0.002)\end{array}$ & $\begin{array}{l}-0.002 \\
(0.002)\end{array}$ & $\begin{array}{c}-0.004 \\
(0.002)\end{array}$ & $\begin{array}{c}0.002 \\
(0.002)\end{array}$ & $\begin{array}{l}-0.003 \\
(0.003)\end{array}$ \\
\hline Region (West=1) & $\begin{array}{c}0.178 * * * \\
(0.046)\end{array}$ & $\begin{array}{l}-0.097^{*} \\
(0.051)\end{array}$ & $\begin{array}{c}0.179 * * * \\
(0.048)\end{array}$ & $\begin{array}{c}0.133^{* * * *} \\
(0.045)\end{array}$ & $\begin{array}{l}0.082 * \\
(0.045)\end{array}$ & $\begin{array}{c}0.006 \\
(0.046)\end{array}$ & $\begin{array}{c}0.055 \\
(0.484)\end{array}$ & $\begin{array}{c}0.016 \\
(0.048)\end{array}$ \\
\hline Years of Schooling & $\begin{array}{c}0.015 * * \\
(0.007)\end{array}$ & $\begin{array}{l}0.013 * \\
(0.008)\end{array}$ & $\begin{array}{c}0.058 * * * \\
(0.008)\end{array}$ & $\begin{array}{c}-0.033^{* * *} \\
(0.007)\end{array}$ & $\begin{array}{l}-0.007 \\
(0.007)\end{array}$ & $\begin{array}{c}0.002 \\
(0.007)\end{array}$ & $\begin{array}{c}-0.023^{* * *} \\
(0.007)\end{array}$ & $\begin{array}{l}-0.012 * \\
(0.007)\end{array}$ \\
\hline \multicolumn{9}{|l|}{ Marital status (base: married): } \\
\hline Separated, divorced, widowed & $\begin{array}{c}0.048 \\
(0.062)\end{array}$ & $\begin{array}{l}0.111^{*} \\
(0.065)\end{array}$ & $\begin{array}{l}-0.018 \\
(0.060)\end{array}$ & $\begin{array}{c}-0.137 * * \\
(0.058)\end{array}$ & $\begin{array}{c}-0.001 \\
(0.058)\end{array}$ & $\begin{array}{c}-0.042 \\
(0.057)\end{array}$ & $\begin{array}{c}0.048 \\
(0.060)\end{array}$ & $\begin{array}{c}-0.056 \\
(0.060)\end{array}$ \\
\hline Single & $\begin{array}{c}0.052 \\
(0.052)\end{array}$ & $\begin{array}{c}0.015 \\
(0.054)\end{array}$ & $\begin{array}{l}-0.035 \\
(0.051)\end{array}$ & $\begin{array}{l}-0.071 \\
(0.048)\end{array}$ & $\begin{array}{l}-0.054 \\
(0.047)\end{array}$ & $\begin{array}{c}0.023 \\
(0.048)\end{array}$ & $\begin{array}{l}-0.018 \\
(0.050)\end{array}$ & $\begin{array}{l}-0.073 \\
(0.051)\end{array}$ \\
\hline Minor child in household (yes=1) & $\begin{array}{c}0.042 \\
(0.041)\end{array}$ & $\begin{array}{l}-0.017 \\
(0.042)\end{array}$ & $\begin{array}{l}-0.072 * \\
(0.040)\end{array}$ & $\begin{array}{c}-0.094^{* *} \\
(0.038)\end{array}$ & $\begin{array}{l}-0.069 * \\
(0.038)\end{array}$ & $\begin{array}{c}0.063 \\
(0.039)\end{array}$ & $\begin{array}{c}0.014 \\
(0.041)\end{array}$ & $\begin{array}{c}0.050 \\
(0.041)\end{array}$ \\
\hline Year (22 dummies) & Yes & Yes & Yes & Yes & Yes & Yes & Yes & Yes \\
\hline $\begin{array}{l}\text { Control for changes in other } \\
\text { attributes ( } 7 * 2 \text { dummies) }\end{array}$ & Yes & Yes & Yes & Yes & Yes & Yes & Yes & Yes \\
\hline \# Observations & 4,861 & 4,861 & 4,861 & 4,861 & 4,861 & 4,861 & 4,861 & 4,861 \\
\hline Pseudo-R² & 0.104 & 0.098 & 0.143 & 0.104 & 0.027 & 0.114 & 0.160 & 0.124 \\
\hline
\end{tabular}

Notes: Robust standard errors in parantheses. ${ }^{*}$ significant at $10 \%,{ }^{* *}$ significant at $5 \%$, *** significant at $1 \%$. 
Table 6: Bivariate correlations between improvements of current and previous job change (Spearman rank correlation coefficients, $n=1,367$ )

\begin{tabular}{|lcccc|}
\hline \multicolumn{1}{|c}{ Job attribute } & $\begin{array}{c}\text { Rank } \\
\text { correlation }\end{array}$ & Significance & $\begin{array}{c}\text { Current } \\
\text { improvements } \\
\text { if previously } \\
\text { improved }\end{array}$ & $\begin{array}{c}\text { Current } \\
\text { improvements } \\
\text { if previously } \\
\text { declined }\end{array}$ \\
\hline Type of work & 0.138 & $\mathrm{p}<0.001$ & 0.640 & 0.531 \\
Pay & 0.137 & $\mathrm{p}<0.001$ & 0.710 & 0.594 \\
Chances of promotion & 0.176 & $\mathrm{p}<0.001$ & 0.543 & 0.376 \\
Work load & 0.140 & $\mathrm{p}<0.001$ & 0.404 & 0.268 \\
Commuting time & 0.105 & $\mathrm{p}<0.001$ & 0.424 & 0.333 \\
Work hour regulation & 0.092 & $\mathrm{p}<0.001$ & 0.499 & 0.422 \\
Fringe benefits & 0.143 & $\mathrm{p}<0.001$ & 0.481 & 0.343 \\
Job security & 0.127 & $\mathrm{p}<0.001$ & 0.457 & 0.281 \\
\hline
\end{tabular}


Table 7: Comparison of studies (Rank of job attributes and correlations of ranks)

\begin{tabular}{|c|c|c|c|c|c|c|}
\hline & \multirow{2}{*}{$\begin{array}{l}\text { This study } \\
\text { Job changes }\end{array}$} & \multicolumn{2}{|c|}{ Jurgensen (1978) } & \multicolumn{2}{|c|}{ Slaughter et al. (2006) } & \multirow{2}{*}{$\begin{array}{l}\text { Skalli et al } \\
\text { (2008) } \\
\text { Importance } \\
\text { of job } \\
\text { satisfaction } \\
\text { facets } \\
(\mathrm{n}=227,379\end{array}$} \\
\hline & & $\begin{array}{c}\text { Own } \\
\text { preferences } \\
(\mathrm{n}=56,621)\end{array}$ & $\begin{array}{c}\text { Preferences } \\
\text { ascribed to } \\
\text { others } \\
(\mathrm{n}=47,948)\end{array}$ & $\begin{array}{l}\text { Direct estimation }{ }^{\#} \\
\qquad(\mathrm{n}=195)\end{array}$ & $\begin{array}{l}\text { Policy } \\
\text { capturing } \\
(\mathrm{n}=203)\end{array}$ & \\
\hline Pay & 1 & 5 & 1 & 1 & 1 & 2 \\
\hline Type of work & 2 & 1 & 4 & 2 & 3 & 1 \\
\hline Chances of promotion & 3 & 3 & 2 & 3 & 6 & \\
\hline Job security & 4 & 2 & 3 & & & 4 \\
\hline Fringe benefits & 5 & 8 & 6 & & & \\
\hline Work hour regulations & 6 & 9 & 5 & 4 & 7 & 5 \\
\hline Work load / conditions & 7 & 10 & 7 & & & 3 \\
\hline Commuting time & 8 & & & 13 & 9 & \\
\hline Company image & & 4 & 8 & & & \\
\hline Co-Workers & & 6 & 10 & 5 & 2 & \\
\hline Supervisor & & 7 & 9 & 6 & 4 & \\
\hline Freedom/autonomy & & & & 7 & 11 & \\
\hline Leadership & & & & 8 & 14 & \\
\hline Authority & & & & 10 & 10 & \\
\hline Prestige/recognition & & & & 9 & 5 & \\
\hline Challenging work & & & & 11 & 13 & \\
\hline Location & & & & 12 & 8 & \\
\hline Dress code & & & & 14 & 12 & \\
\hline \multicolumn{7}{|c|}{ Spearman rank correlations across studies } \\
\hline This study & 1 & & & & & \\
\hline $\begin{array}{l}\text { Jurgensen (1978) } \\
\text { Own preferences }\end{array}$ & $\begin{array}{c}0.750^{*} \\
(\mathrm{p}=0.052, \mathrm{n}=7)\end{array}$ & 1 & & & & \\
\hline $\begin{array}{l}\text { Jurgensen (1978) } \\
\text { Pref. ascribed to others }\end{array}$ & $\begin{array}{c}0.857 * * \\
(\mathrm{p}=0.014, \mathrm{n}=7)\end{array}$ & $\begin{array}{c}0.442 \\
(p=0.200, n=10)\end{array}$ & 1 & & & \\
\hline $\begin{array}{l}\text { Slaughter et al. (2006) } \\
\text { Direct estimation }\end{array}$ & $\begin{array}{l}1 * * * \\
(\mathrm{n}=5)\end{array}$ & $\begin{array}{c}0.657 \\
(p=0.156, n=6)\end{array}$ & $\begin{array}{c}0.886^{* *} \\
(\mathrm{p}=0.019, \mathrm{n}=6)\end{array}$ & 1 & & \\
\hline $\begin{array}{l}\text { Slaughter et al. (2006) } \\
\text { Policy capturing }\end{array}$ & $\begin{array}{l}1 * * * \\
(\mathrm{n}=5)\end{array}$ & $\begin{array}{c}0.371 \\
(p=0.468, n=6)\end{array}$ & $\begin{array}{c}0.143 \\
(p=0.787, n=6)\end{array}$ & $\begin{array}{c}0.692 * * * \\
(\mathrm{p}=0.006, \mathrm{n}=14)\end{array}$ & 1 & \\
\hline Skalli et al. (2008) & $\begin{array}{c}0.600 \\
(\mathrm{p}=0.285, \mathrm{n}=5)\end{array}$ & $\begin{array}{c}0.500 \\
(\mathrm{p}=0.391, \mathrm{n}=5)\end{array}$ & $\begin{array}{c}0.300 \\
(p=0.624, n=5)\end{array}$ & $\begin{array}{c}0.500 \\
(\mathrm{p}=0.667, \mathrm{n}=3)\end{array}$ & $\begin{array}{c}0.500 \\
(\mathrm{n}=0.667, \mathrm{n}=3)\end{array}$ & 1 \\
\hline
\end{tabular}

\# Average \#of three questions (Rating, ranking, distribution of points). § Effect on overall job satisfaction, average of ten European countries. * significant at $10 \%, * *$ significant at $5 \%$, *** significant at $1 \%$. 


\section{Appendix}

Figure A1: Fraction of Improvements and Declines by job characteristic, period of time and region
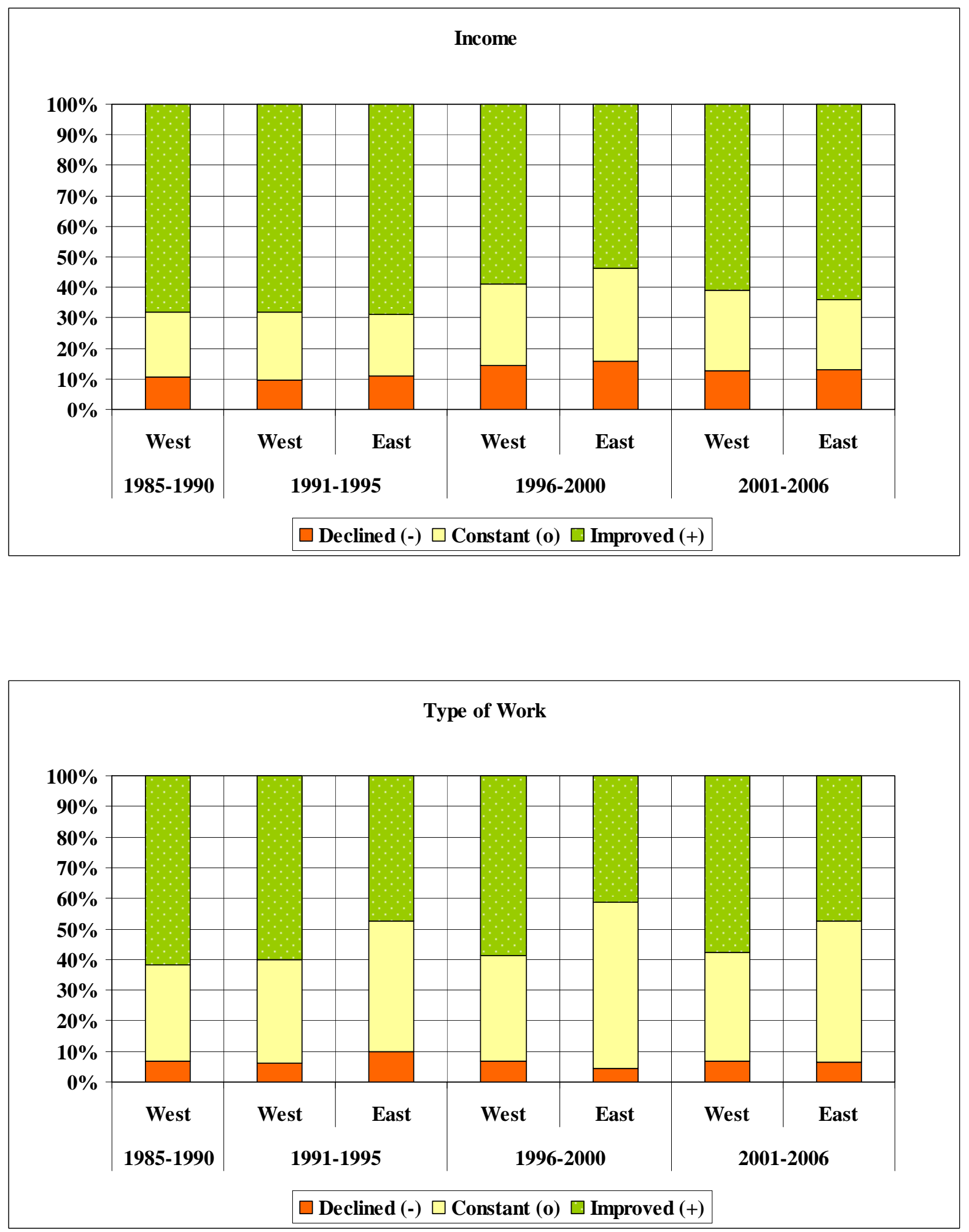
Figure A1: continued
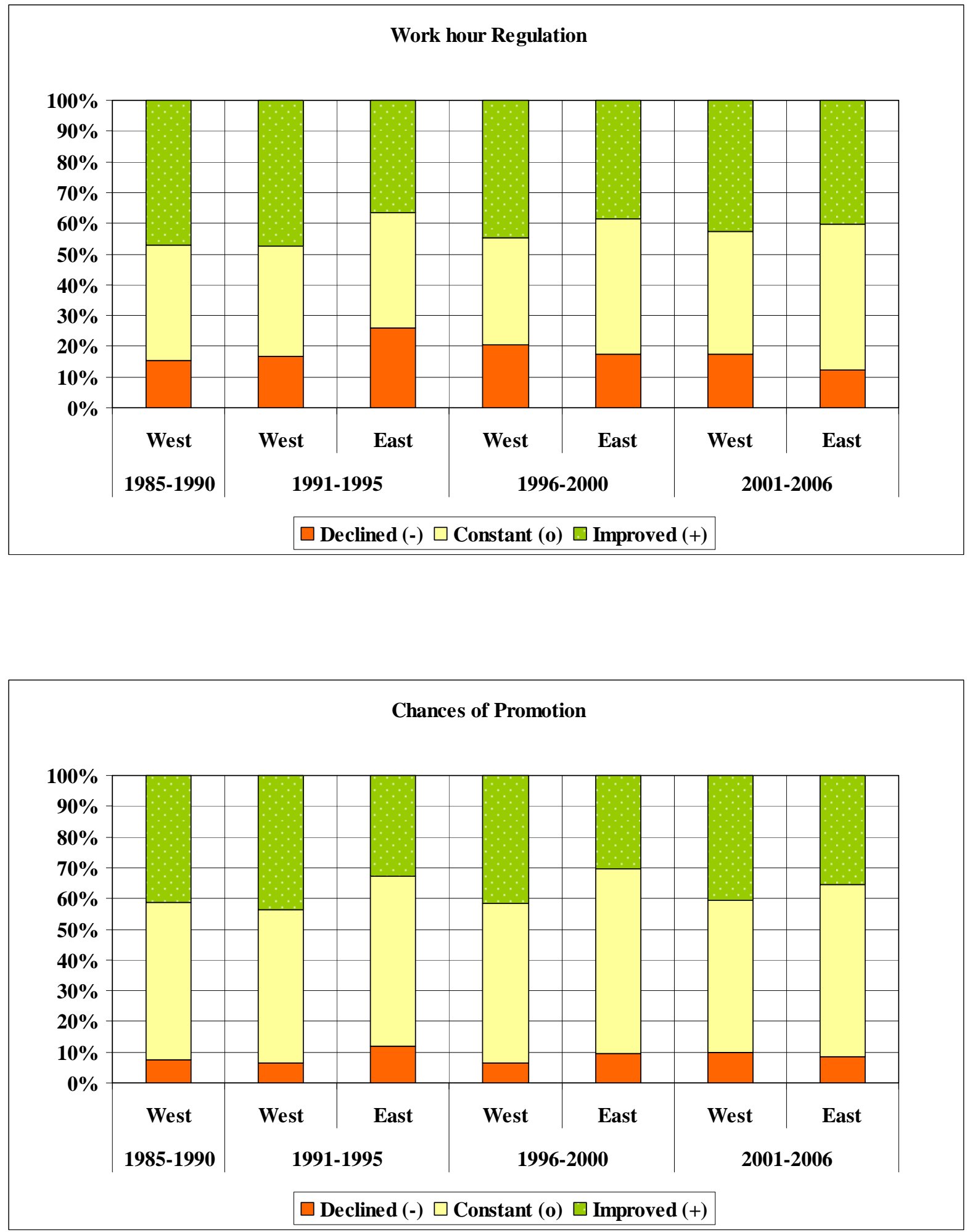
Figure A1: continued
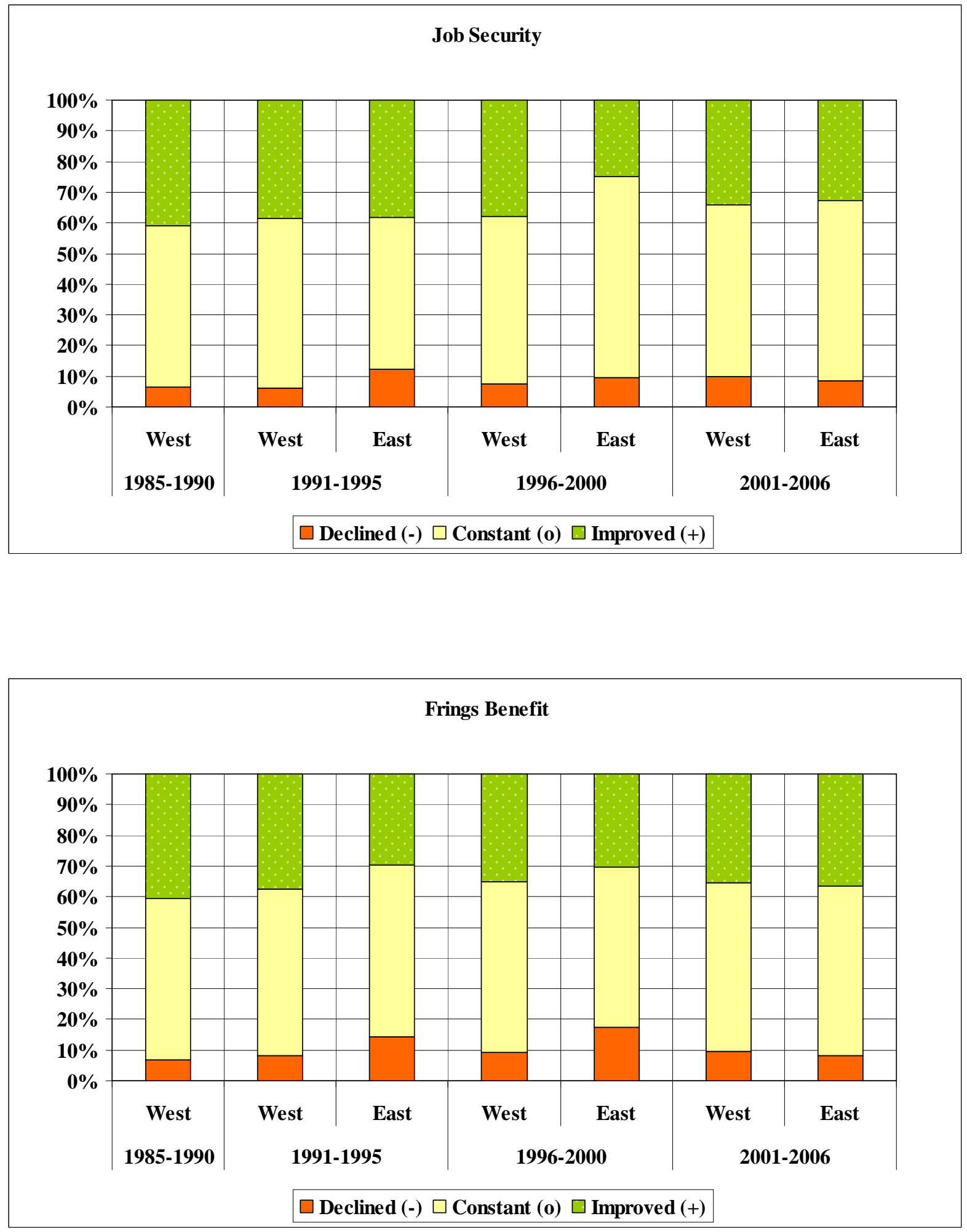
Figure A1: continued
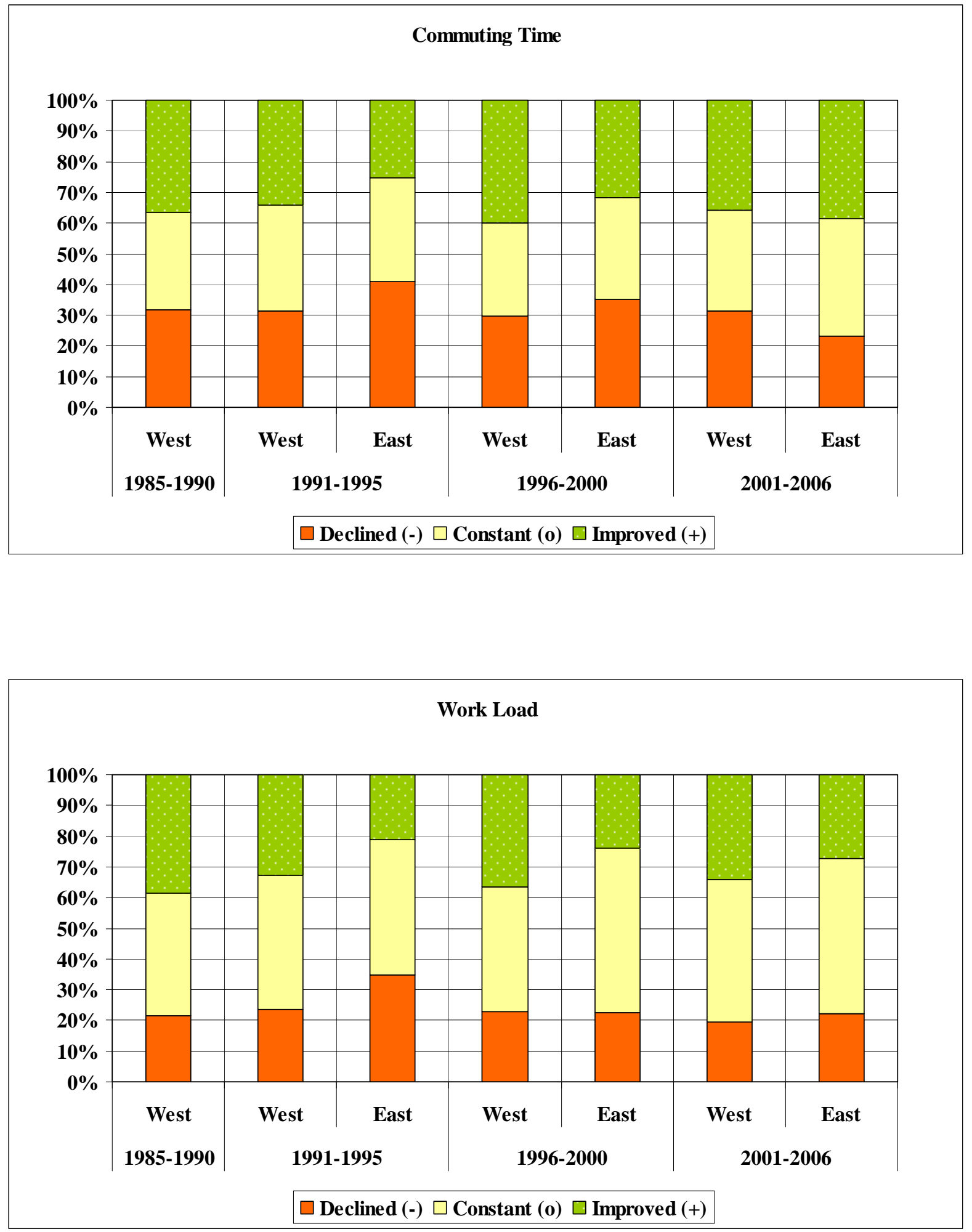
Table A1: Improvements and declines of job attributes by age and schooling - rank in parantheses (criterion: fraction improvements - fraction declines)

\begin{tabular}{|c|c|c|c|c|c|c|c|c|c|c|c|c|c|c|}
\hline & & \multicolumn{2}{|c|}{$\begin{array}{c}\text { Whole } \\
\text { sample } \\
\text { (n=4861) }\end{array}$} & \multicolumn{2}{|c|}{$\begin{array}{c}\text { Younger } \\
\text { than } 40 \\
\text { years } \\
\\
(n=3,763) \\
\end{array}$} & \multicolumn{2}{|c|}{$\begin{array}{c}\text { At least } 40 \\
\text { years old } \\
(n=1,098) \\
\end{array}$} & \multirow[t]{2}{*}{$\begin{array}{c}\text { K-S-Test } \\
\text { (age) }\end{array}$} & \multicolumn{3}{|c|}{$\begin{array}{c}\text { At least } 15 \\
\text { years of } \\
\text { schooling }^{\#} \\
(n=787) \\
\end{array}$} & \multicolumn{2}{|c|}{$\begin{array}{c}\text { Less than } 15 \\
\text { years of } \\
\text { schooling } \\
(n=4,074) \\
\end{array}$} & \multirow[t]{2}{*}{$\begin{array}{l}\text { K-S-Test } \\
\text { (schooling) }\end{array}$} \\
\hline & - & 0.119 & & 0.115 & & 0.135 & & & - & 0.100 & & 0.123 & & \\
\hline Pay & $\mathbf{0}$ & 0.240 & [1] & 0.222 & [1] & 0.304 & [2] & $* * *$ & $\mathbf{0}$ & 0.250 & [2] & 0.239 & [1] & n. s. \\
\hline & + & 0.640 & & 0.664 & & 0.561 & & & + & 0.649 & & 0.639 & & \\
\hline & - & 0.068 & & 0.068 & & 0.070 & & & - & 0.055 & & 0.070 & & \\
\hline \multirow[t]{3}{*}{ Type of work } & $\mathbf{0}$ & 0.362 & [2] & 0.352 & [2] & 0.396 & [1] & $* *$ & $\mathbf{0}$ & 0.341 & [1] & 0.366 & [2] & n. s. \\
\hline & + & 0.570 & & 0.581 & & 0.534 & & & + & 0.605 & & 0.564 & & \\
\hline & - & 0.083 & & 0.081 & & 0.092 & & & - & 0.084 & & 0.083 & & \\
\hline \multirow[t]{3}{*}{ Chances of promotion } & $\mathbf{0}$ & 0.516 & [3] & 0.487 & [3] & 0.617 & [5] & $* * *$ & $\mathbf{0}$ & 0.394 & [3] & 0.540 & [4] & $* * *$ \\
\hline & + & 0.401 & & 0.432 & & 0.291 & & & + & 0.522 & & 0.377 & & \\
\hline & - & 0.082 & & 0.077 & & 0.100 & & & - & 0.123 & & 0.074 & & \\
\hline \multirow[t]{3}{*}{ Job security } & $\mathbf{0}$ & 0.548 & [4] & 0.541 & [4] & 0.570 & [3] & $* *$ & $\mathbf{0}$ & 0.507 & [4] & 0.556 & [3] & $*$. \\
\hline & + & 0.370 & & 0.382 & & 0.330 & & & + & 0.370 & & 0.370 & & \\
\hline & - & 0.094 & & 0.090 & & 0.109 & & & - & 0.131 & & 0.087 & & \\
\hline \multirow[t]{3}{*}{ Fringe benefits } & $\mathbf{0}$ & 0.543 & [5] & 0.537 & [5] & 0.566 & [4] & $* *$ & $\mathbf{0}$ & 0.506 & [5] & 0.553 & [6] & n. s. \\
\hline & + & 0.362 & & 0.373 & & 0.325 & & & + & 0.363 & & 0.362 & & \\
\hline & - & 0.180 & & 0.177 & & 0.190 & & & - & 0.214 & & 0.174 & & \\
\hline \multirow[t]{3}{*}{ Work hours regulations } & $\mathbf{0}$ & 0.380 & [6] & 0.365 & [6] & 0.431 & [6] & $* * *$ & $\mathbf{0}$ & 0.404 & [6] & 0.387 & [5] & $* * *$ \\
\hline & + & 0.440 & & 0.458 & & 0.379 & & & + & 0.383 & & 0.452 & & \\
\hline & - & 0.231 & & 0.223 & & 0.256 & & & - & 0.334 & & 0.210 & & \\
\hline \multirow[t]{3}{*}{ Work load } & $\mathbf{0}$ & 0.436 & [7] & 0.430 & [7] & 0.457 & [8] & $* * *$ & $\mathbf{0}$ & 0.372 & [8] & 0.449 & [7] & $* * *$ \\
\hline & + & 0.333 & & 0.347 & & 0.287 & & & + & 0.294 & & 0.341 & & \\
\hline & - & 0.320 & & 0.321 & & 0.316 & & & - & 0.356 & & 0.313 & & \\
\hline \multirow[t]{2}{*}{ Commuting time } & $\mathbf{0}$ & 0.328 & [8] & 0.319 & [8] & 0.358 & [7] & n. s. & $\mathbf{0}$ & 0.311 & [7] & 0.331 & [8] & n. s. \\
\hline & + & 0.353 & & 0.360 & & 0.326 & & & + & 0.333 & & 0.356 & & \\
\hline
\end{tabular}

Notes: ${ }^{\#}$ This group includes graduates from universities and universities of applied sciences. K-S-Tests indicate Kolmogorov-Smirnov tests of identical distributions of changes in job attributes of sex and region: ${ }^{*}$ significant at $10 \%$, ${ }^{* *}$ significant at $5 \%,{ }^{* * *}$ significant at $1 \%$, n. s. $=$ not significant. 
Table A2a: Determinants of Improvements in Subperiods (Ordered Probit Model, $-1=$ declined, $0=$ constant, $1=$ improved)

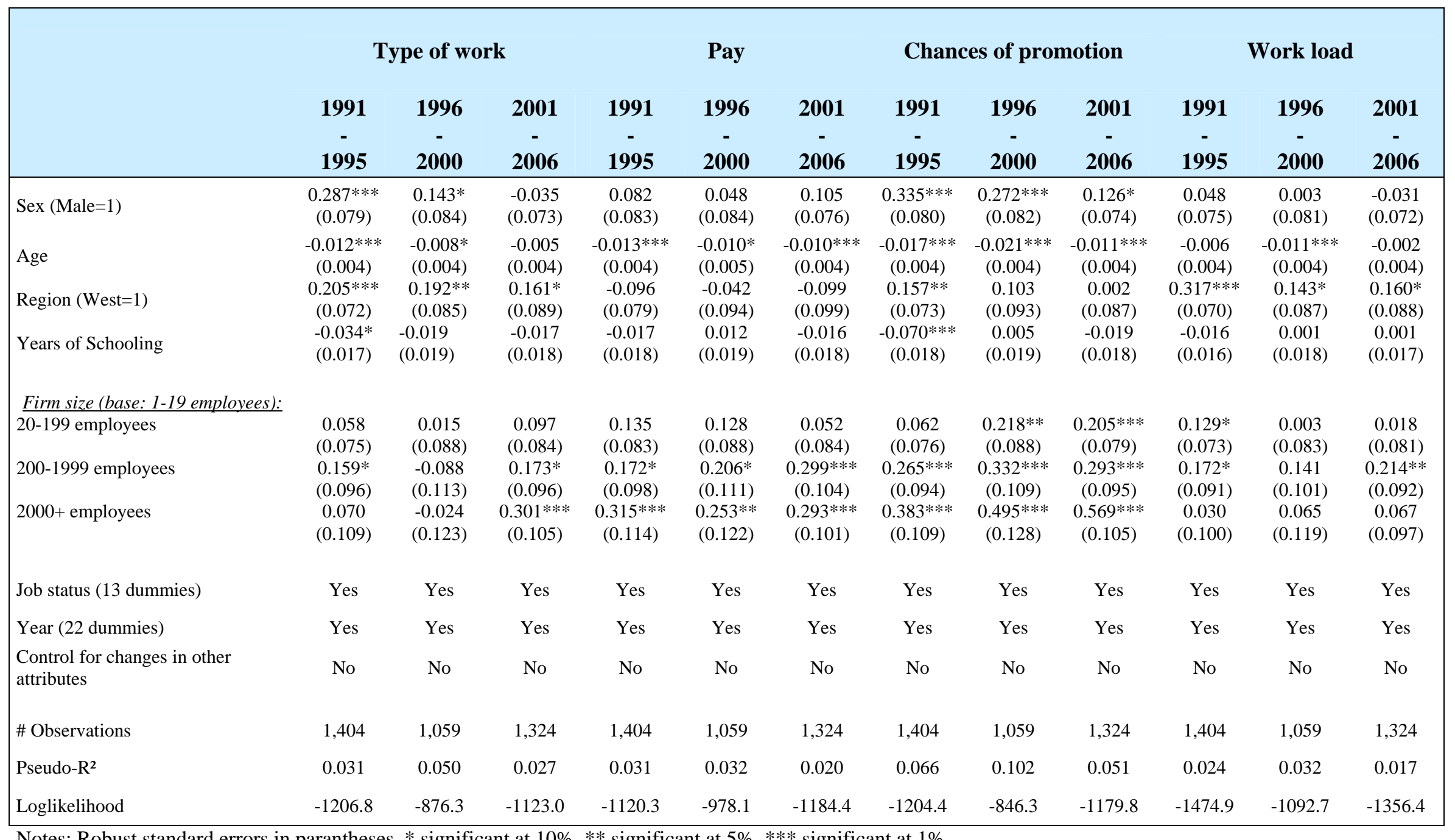

Notes: Robust standard errors in parantheses. * significant at $10 \%, * *$ significant at $5 \%,{ }^{* * *}$ significant at $1 \%$. 
Table A2b: Determinants of Improvements in Subperiods (Ordered Probit Model, $-1=$ declined, $0=$ constant, $1=$ improved)

\begin{tabular}{|c|c|c|c|c|c|c|c|c|c|c|c|c|}
\hline & \multicolumn{3}{|c|}{ Commuting time } & \multicolumn{3}{|c|}{ Work hour regulation } & \multicolumn{3}{|c|}{ Fringe benefits } & \multicolumn{3}{|c|}{ Job security } \\
\hline & $\begin{array}{c}1991 \\
- \\
1995\end{array}$ & $\begin{array}{c}1996 \\
- \\
2000\end{array}$ & $\begin{array}{c}2001 \\
- \\
2006\end{array}$ & $\begin{array}{c}1991 \\
- \\
1995\end{array}$ & $\begin{array}{c}1996 \\
- \\
2000\end{array}$ & $\begin{array}{c}2001 \\
- \\
2006\end{array}$ & $\begin{array}{c}1991 \\
- \\
1995\end{array}$ & $\begin{array}{c}1996 \\
- \\
2000\end{array}$ & $\begin{array}{c}2001 \\
- \\
2006\end{array}$ & $\begin{array}{c}1991 \\
- \\
1995\end{array}$ & $\begin{array}{c}1996 \\
- \\
2000\end{array}$ & $\begin{array}{c}2001 \\
- \\
2006\end{array}$ \\
\hline Sex $($ Male=1) & $\begin{array}{c}0.012 \\
(0.072)\end{array}$ & $\begin{array}{l}-0.132 * \\
(0.080)\end{array}$ & $\begin{array}{c}-0.042 \\
(0.070)\end{array}$ & $\begin{array}{c}0.014 \\
(0.076)\end{array}$ & $\begin{array}{c}-0.185^{* *} \\
(0.083)\end{array}$ & $\begin{array}{c}-0.162^{* *} \\
(0.072)\end{array}$ & $\begin{array}{c}0.041 \\
(0.078)\end{array}$ & $\begin{array}{c}-0.001 \\
(0.082)\end{array}$ & $\begin{array}{l}-0.105 \\
(0.073)\end{array}$ & $\begin{array}{c}0.166^{* *} \\
(0.077)\end{array}$ & $\begin{array}{c}0.159 * * \\
(0.081)\end{array}$ & $\begin{array}{c}0.008 \\
(0.074)\end{array}$ \\
\hline Age & $\begin{array}{l}-0.002 \\
(0.004)\end{array}$ & $\begin{array}{c}0.005 \\
(0.004)\end{array}$ & $\begin{array}{l}-0.002 \\
(0.004)\end{array}$ & $\begin{array}{c}-0.009 * * \\
(0.004)\end{array}$ & $\begin{array}{l}-0.001 \\
(0.004)\end{array}$ & $\begin{array}{l}-0.005 \\
(0.004)\end{array}$ & $\begin{array}{l}-0.006 \\
(0.004)\end{array}$ & $\begin{array}{c}-0.009 * * \\
(0.004)\end{array}$ & $\begin{array}{c}0.003 \\
(0.004)\end{array}$ & $\begin{array}{c}-0.004 \\
(0.004)\end{array}$ & $\begin{array}{c}-0.006 \\
(0.004)\end{array}$ & $\begin{array}{l}-0.001 \\
(0.004)\end{array}$ \\
\hline Region (West=1) & $\begin{array}{c}0.301 * * * \\
(0.070)\end{array}$ & $\begin{array}{l}0.174^{*} \\
(0.092)\end{array}$ & $\begin{array}{l}-0.144 \\
(0.088)\end{array}$ & $\begin{array}{c}0.274 * * * \\
(0.071)\end{array}$ & $\begin{array}{l}-0.009 \\
(0.087)\end{array}$ & $\begin{array}{l}-0.072 \\
(0.086)\end{array}$ & $\begin{array}{c}0.148 * * \\
(0.072)\end{array}$ & $\begin{array}{c}0.144 \\
(0.095)\end{array}$ & $\begin{array}{l}-0.099 \\
(0.091)\end{array}$ & $\begin{array}{c}0.071 \\
(0.075)\end{array}$ & $\begin{array}{c}0.224 * * \\
(0.091)\end{array}$ & $\begin{array}{l}-0.013 \\
(0.089)\end{array}$ \\
\hline Years of Schooling & $\begin{array}{c}0.023 \\
(0.016)\end{array}$ & $\begin{array}{l}-0.016 \\
(0.018)\end{array}$ & $\begin{array}{c}0.018 \\
(0.017)\end{array}$ & $\begin{array}{c}0.015 \\
(0.017)\end{array}$ & $\begin{array}{l}-0.013 \\
(0.017)\end{array}$ & $\begin{array}{l}-0.005 \\
(0.017)\end{array}$ & $\begin{array}{l}-0.015 \\
(0.018)\end{array}$ & $\begin{array}{l}-0.012 \\
(0.018)\end{array}$ & $\begin{array}{c}-0.044^{* *} \\
(0.017)\end{array}$ & $\begin{array}{l}-0.020 \\
(0.017)\end{array}$ & $\begin{array}{r}-0.0003 \\
(0.019)\end{array}$ & $\begin{array}{c}-0.037 * * \\
(0.018)\end{array}$ \\
\hline \multicolumn{13}{|l|}{ Firm size (base: 1 -19 employees): } \\
\hline 20-199 employees & $\begin{array}{c}0.034 \\
(0.074)\end{array}$ & $\begin{array}{c}-0.112 \\
(0.084)\end{array}$ & $\begin{array}{c}0.084 \\
(0.080)\end{array}$ & $\begin{array}{l}0.144^{*} \\
(0.074)\end{array}$ & $\begin{array}{c}0.037 \\
(0.084)\end{array}$ & $\begin{array}{c}0.191 * * \\
(0.081)\end{array}$ & $\begin{array}{c}0.395 * * * \\
(0.073)\end{array}$ & $\begin{array}{c}0.121 \\
(0.084)\end{array}$ & $\begin{array}{c}0.223 * * * \\
(0.079)\end{array}$ & $\begin{array}{c}0.035 \\
(0.075)\end{array}$ & $\begin{array}{c}0.218 * * * \\
(0.084)\end{array}$ & $\begin{array}{c}0.211 * * * \\
(0.080)\end{array}$ \\
\hline 200-1999 employees & $\begin{array}{l}-0.113 \\
(0.087)\end{array}$ & $\begin{array}{l}-0.143 \\
(0.106)\end{array}$ & $\begin{array}{l}-0.083 \\
(0.095)\end{array}$ & $\begin{array}{c}0.119 \\
(0.090)\end{array}$ & $\begin{array}{c}0.148 \\
(0.106)\end{array}$ & $\begin{array}{c}0.201^{* *} \\
(0.093)\end{array}$ & $\begin{array}{c}0.589 * * * \\
(0.096)\end{array}$ & $\begin{array}{c}0.440 * * * \\
(0.110)\end{array}$ & $\begin{array}{c}0.514 * * * \\
(0.098)\end{array}$ & $\begin{array}{l}0.176^{*} \\
(0.093)\end{array}$ & $\begin{array}{c}0.370^{* * *} \\
(0.112)\end{array}$ & $\begin{array}{c}0.261^{* * *} \\
(0.093)\end{array}$ \\
\hline 2000+ employees & $\begin{array}{c}-0.335^{* * *} \\
(0.099)\end{array}$ & $\begin{array}{l}-0.177 \\
(0.116)\end{array}$ & $\begin{array}{l}-0.122 \\
(0.094)\end{array}$ & $\begin{array}{c}0.236^{* *} \\
(0.102)\end{array}$ & $\begin{array}{c}0.251^{* *} \\
(0.121)\end{array}$ & $\begin{array}{c}0.226^{* *} \\
(0.099)\end{array}$ & $\begin{array}{c}0.942 * * * \\
(0.107)\end{array}$ & $\begin{array}{c}0.836 * * * \\
(0.120)\end{array}$ & $\begin{array}{c}0.637 * * * \\
(0.098)\end{array}$ & $\begin{array}{c}0.342^{* * *} \\
(0.106)\end{array}$ & $\begin{array}{c}0.560 * * * \\
(0.123)\end{array}$ & $\begin{array}{c}0.360^{* * *} \\
(0.099)\end{array}$ \\
\hline Job status (13 dummies) & Yes & Yes & Yes & Yes & Yes & Yes & Yes & Yes & Yes & Yes & Yes & Yes \\
\hline Year (22 dummies) & Yes & Yes & Yes & Yes & Yes & Yes & Yes & Yes & Yes & Yes & Yes & Yes \\
\hline $\begin{array}{l}\text { Control for changes in other } \\
\text { attributes }\end{array}$ & No & No & No & No & No & No & No & No & No & No & No & No \\
\hline \# Observations & 1,404 & 1,059 & 1,324 & 1,404 & 1,059 & 1,324 & 1,404 & 1,059 & 1,324 & 1,404 & 1,059 & 1,324 \\
\hline Pseudo-R² & 0.017 & 0.013 & 0.012 & 0.021 & 0.020 & 0.020 & 0.053 & 0.045 & 0.031 & 0.019 & 0.031 & 0.013 \\
\hline Loglikelihood & -1516.8 & -1142.6 & -1433.8 & -1446.4 & -1090.5 & -1333.6 & -1240.7 & -948.7 & -1176.6 & -1254.5 & -912.0 & -1199.2 \\
\hline
\end{tabular}


Table A3: Determinants of Job Satisfaction\# (Ordered Probit Model, $n=4,861$ )

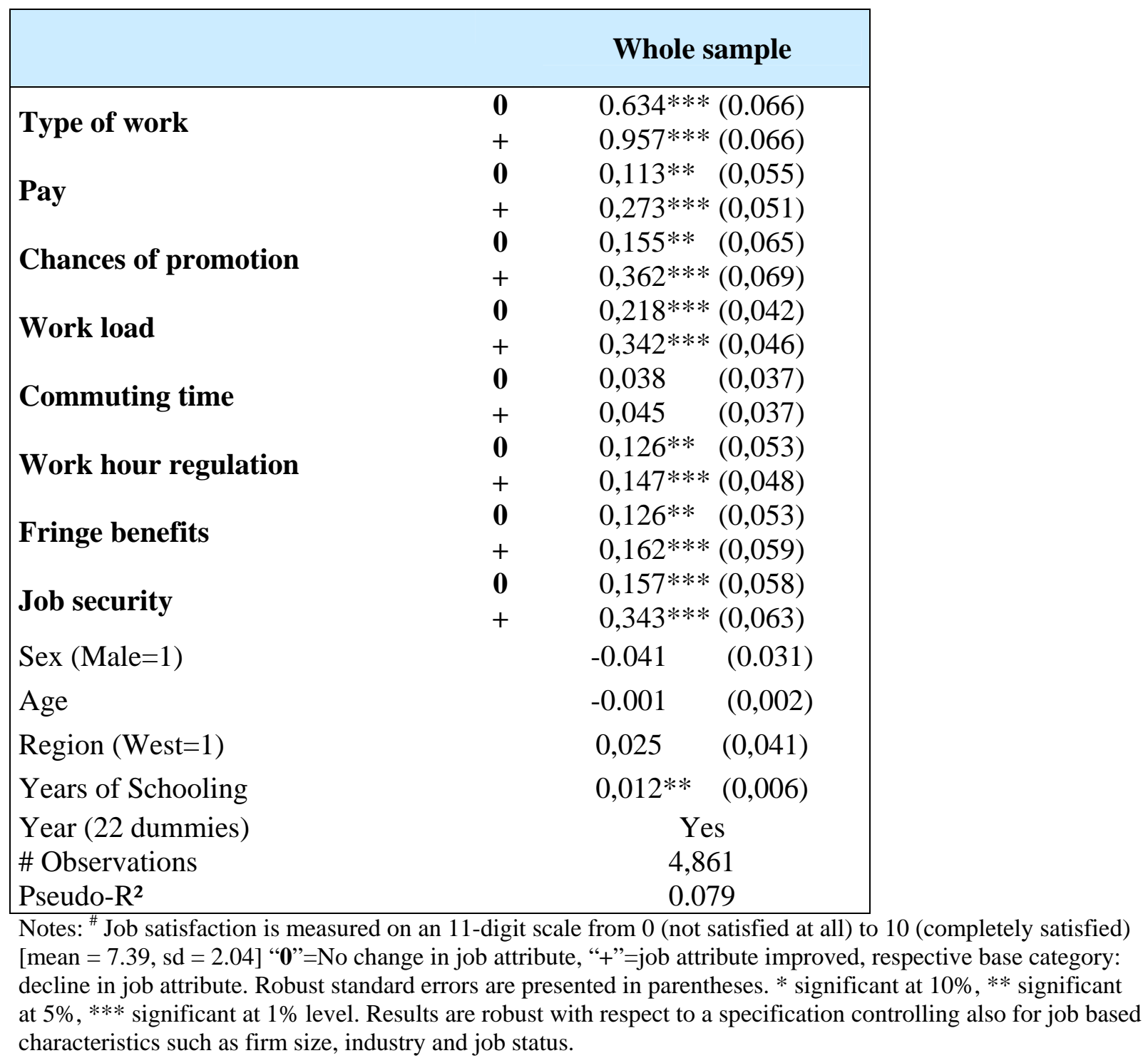

